\title{
Mammoth Cave: A Hotspot of Subterranean Biodiversity in the United States
}

\author{
Matthew L. Niemiller ${ }^{1, *}$, Kurt Helf ${ }^{2}$ and Rickard S. Toomey ${ }^{3}$ \\ 1 Department of Biological Sciences, The University of Alabama in Huntsville, 301 Sparkman Dr NW, \\ Huntsville, AL 35899, USA \\ 2 Cumberland Piedmont Network, National Park Service, Mammoth Cave National Park, 61 Maintenance Rd., \\ Mammoth Cave, KY 42259, USA; kurt_helf@nps.gov \\ 3 Division of Science and Resources Management, Mammoth Cave National Park, P.O. Box 7, \\ Mammoth Cave, KY 42259, USA; rick_toomey@nps.gov \\ * Correspondence: matthew.niemiller@uah.edu or cavemander17@gmail.com
}

Citation: Niemiller, M.L.; Helf, K.; Toomey, R.S. Mammoth Cave: A Hotspot of Subterranean Biodiversity in the United States. Diversity 2021, 13, 373. https://doi.org/10.3390/ d13080373

Academic Editors: Tanja Pipan, David C. Culver and Louis Deharveng

Received: 10 July 2021

Accepted: 3 August 2021

Published: 12 August 2021

Publisher's Note: MDPI stays neutral with regard to jurisdictional claims in published maps and institutional affiliations.

Copyright: (c) 2021 by the authors. Licensee MDPI, Basel, Switzerland. This article is an open access article distributed under the terms and conditions of the Creative Commons Attribution (CC BY) license (https:// creativecommons.org/licenses/by/ $4.0 /)$.

\begin{abstract}
The Mammoth Cave System in the Interior Low Plateau karst region in central Kentucky, USA is a global hotspot of cave-limited biodiversity, particularly terrestrial species. We searched the literature, museum accessions, and database records to compile an updated list of troglobiotic and stygobiotic species for the Mammoth Cave System and compare our list with previously published checklists. Our list of cave-limited fauna totals 49 species, with 32 troglobionts and 17 stygobionts. Seven species are endemic to the Mammoth Cave System and other small caves in Mammoth Cave National Park. The Mammoth Cave System is the type locality for 33 cave-limited species. The exceptional diversity at Mammoth Cave is likely related to several factors, such as the high dispersal potential of cave fauna associated with expansive karst exposures, high surface productivity, and a long history of exploration and study. Nearly $80 \%$ of the cave-limited fauna is of conservation concern, many of which are at an elevated risk of extinction because of small ranges, few occurrences, and several potential threats.
\end{abstract}

Keywords: checklist; karst; species richness; stygobiont; troglobiont

\section{Introduction}

The Mammoth Cave System in central Kentucky, USA is the most extensive cave system in the world with over $663 \mathrm{~km}$ (412 miles) of mapped passaged, including 27 entrances and 10 significant caves that have been connected since explorations began in the late 1700s: Colossal, Crystal (=Floyd Collins' Crystal), Donkey, Hoover, Mammoth, Morrison, Proctor, Roppel, Salts, and Unknown caves. Colossal, Crystal, Salts, and Unknown caves comprise the 206 km (128 mile) Flint Ridge Cave system (Figure 1). Mammoth Cave National Park was created in 1941 and includes two-thirds of the Mammoth Cave System [1]. The Mammoth Cave System was recognized as a UNESCO World Heritage Site in 1981 because of its uniqueness as the world's longest cave system as well as its extensive geological, mineral, and biological resources. The region was recognized as the core of an UNESCO Biosphere Reserve-Mammoth Cave Biosphere Region-in 1990.

The Mammoth Cave System is developed in three major limestone layers at the northwestern extent of the Pennyroyal Plateau, an expansive flat karst plain within the Interior Low Plateau physiographic province. The limestone layers include, from youngest to oldest, the Girkin Formation (40 m thick), Ste. Genevieve Limestone (35 m thick), and St. Louis Limestone (53-60 m thick) [2-5]. The Girkin Formation is capped by resistant sandstone and shale of the Big Clifty Formation that form the Mammoth Cave, Flint, Joppa, and Toohey Ridges. Most of the cave system is developed in the Ste. Genevieve Limestone and the upper $40 \mathrm{~m}$ of St. Louis Limestone [5]. The limestone strata gently slope from the southeast to the northwest. The Pennyroyal Plateau is exposed at the surface to the 
southeast, while insoluble strata of the Chester Upland, including the Big Clifty Formation, form a rugged hilly terrain that overlies the cave system to the northwest. The Green River, a tributary of the Ohio River, has cut into the Pennyroyal Plateau about $60 \mathrm{~m}$ such that most of the Mammoth Cave watershed now occurs underground [6]. The karst watershed of Mammoth Cave includes seven groundwater basins (Pike Spring, Great Onyx, Echo River, Double Sink, River Styx, Floating Mill Hollow, and Turnhole Bend); in addition, flood overflow occurs into an eighth basin (Sand Cave). These basins encompass $317 \mathrm{~km}^{2}$ and ultimately drain at springs at base level into the Green River $[7,8]$.

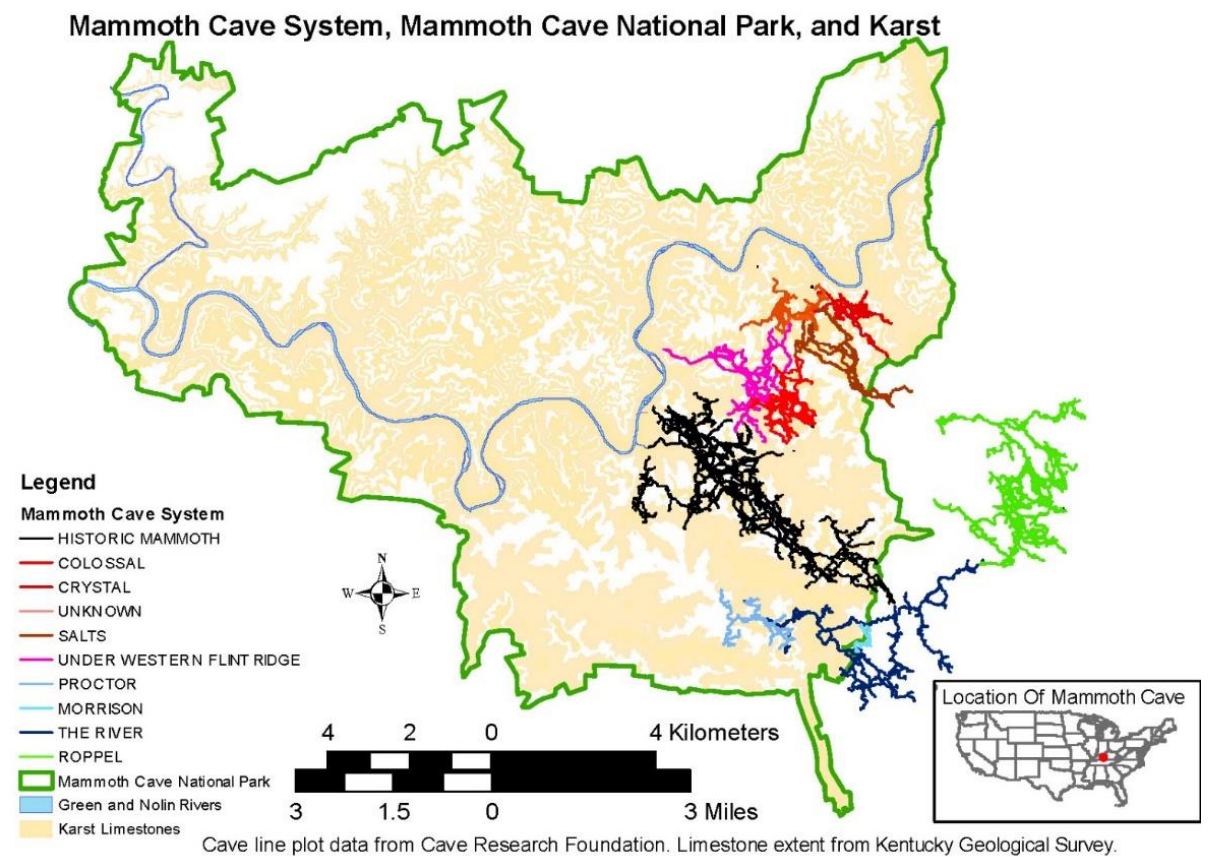

Figure 1. Map showing the location of Mammoth Cave National Park (MCNP) and the extent of the Mammoth Cave System in and adjacent to MCNP. The major segments of the Mammoth Cave System are shown as line plots in various colors. The different segments explored from different entrances (27 total). Line plot data from Cave Research Foundation. MCNP also contains over 500 smaller caves developed in various karstified limestones that are not attached to the Mammoth Cave System. These are grouped on the map, but include the St. Louis, Ste. Genevieve, Haney, Glen Dean and Girkin Formations. These smaller caves contain a variety of habitats from epikarst to base-level streams.

The Mammoth Cave System is characterized by a complex network of vadose and phreatic passages with at least five primary horizontal levels of passages (four fossil stream levels and the modern base level) representing distinct stages of development in association with past periods of water table stability and intervening periods of downcutting of the Green River valley through the resistant caprock into the soluble limestone layers below $[1,6]$. The evolution of the Mammoth Cave system is linked to the incision history of the Green River, drainage reorganizations, and significant climatic changes from the Pliocene through the Pleistocene, with the oldest upper-level passages dating to 3.2 Mya and the lower levels developing over the past 2 Mya [9].

Mammoth Cave has long been a focal region of study for North American subterranean biodiversity and for advancing our foundational knowledge of the ecology and evolution of cave fauna. Studies of the biodiversity in the Mammoth Cave System have an extensive history dating back to the 1820s (see [10]) when Constantin S. Rafinesque first visited Mammoth Cave [11]. Darwin [12] even mentions cave life from the Mammoth Cave region in On the Origin of Species by Means of Natural Selection. Much of our early knowledge of the North American cave fauna was derived from visits and studies by biologists to Mammoth Cave in the 1800s, such as DeKay [13], Wyman [14-19], Tellkampf [20-22], Agassiz [23-25], Von Motschulsky [26,27], Call [28], and Packard [29-36] (reviewed in [10] and [37]). 
Additional significant early publications on the fauna and ecology of Mammoth Cave include Putnam [38], Eigenmann [39-42], Bolivar and Jeannel [43], Bailey [44], Buchanan [45], Park [46], Dearolf [47], Hubricht [48-53], Jeannel and Henrot [54], and Barr [55-60]. Barr [10] provided the first comprehensive review of the fauna of the Mammoth Cave system. More recently, Poulson [61,62] and Helf and Olson [63] provided reviews of terrestrial and aquatic ecosystems in Mammoth Cave. Culver and Hobbs [37] comprehensively reviewed the obligate cave fauna of the Mammoth Cave system and compared the fauna with other global hotspots of terrestrial cave biodiversity. Toomey et al. [1] presented a general review of the Mammoth Cave system that included a checklist of cave obligate fauna.

Herein we present an updated list of terrestrial and aquatic cave obligate fauna (i.e., troglobionts and stygobionts, respectively) of the Mammoth Cave system. Our goal is not to duplicate recently published checklists by Culver and Hobbs [37] and Toomey et al. [1] but rather complement these works by including a comprehensive bibliography on the cave obligate fauna of Mammoth Cave. In addition, we compare our list with past checklists from Mammoth Cave and comment on the exceptional biodiversity of this North American and global hotspot of subterranean biodiversity.

\section{Materials and Methods}

We conducted a search of the scientific literature to compile an updated list of troglobiont and stygobiont species for the Mammoth Cave System. For an overview of taxa that are not cave-limited, we refer readers to Barr [10], Culver and Hobbs [37], Helf and Olson [63], and Poulson [62]. Scientific literature sources included journal articles, book chapters, books, conference proceedings, theses and dissertations, and government reports. Searches of literature sources included keyword queries of ISI Web of Science, Google Scholar, and Zoological Record. In addition, we also searched biodiversity databases including the Global Biodiversity Information Facility (GBIF; Available online: https: / gbif.org (accessed on 28 June 2021)), VertNet (Available online: http:/ / www.vertnet.org (accessed on 28 June 2021)), Symbiota Collections of Arthropods Network (SCAN; Available online: https://scan-bugs.org/portal/(accessed on 28 June 2021)), and InvertEBase (Available online: http:/ / www.invertebase.org/portal/index.php (accessed on 28 June 2021)). The list of cave obligate fauna includes the scientific name, authority, and conservation status of each species. Taxonomic nomenclature followed primarily the Integrated Taxonomic Information System (ITIS; Available online: http:/ /itis.gov (accessed on 28 June 2021)). For conservation status, we include the International Union for Conservation of Nature (IUCN) Red List of Threatened Species (Available online: http:/ / www.iucnredlist.org (accessed on 28 June 2021)) and NatureServe (Available online: http:/ / www.natureserve.org (accessed on 28 June 2021)) conservation statuses when available. The status of a species according to the United States list of threatened and endangered species under the U.S. Endangered Species Act is included (Available online: http:/ / www.fws.gov / endangered (accessed on 28 June 2021)), as well its status (endangered, threatened, or of greatest conservation need) under the latest Kentucky State Wildlife Action Plan (Available online: https: / / fw.ky.gov/WAP/Pages/default.aspx (accessed on 28 June 2021)).

\section{Results}

Packard [36] summarized the North America cave fauna, which at that time was primarily limited to the fauna of Mammoth Cave. He reported 31 permanent cave species, 18 of which we recognize as cave-limited species today, including 12 troglobionts and six stygobionts (Table 1). Barr [10] reported 44 cave-limited species (28 troglobionts and 16 stygobionts). More recently, Culver and Hobbs [37] listed 48 species (32 troglobionts and 16 stygobionts, 11 of which (nine troglobionts and two stygobionts) are endemic to the Mammoth Cave System, while Toomey et al. [1] reported 50 cave-limited species (32 troglobionts and 18 stygobionts). The authors also included two springtails not yet identified to species (Willemia sp. and Onychiurus sp.) on their list of cave-limited taxa, which were also reported by Barr [10]. 


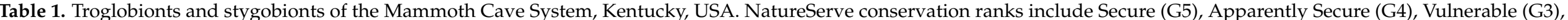

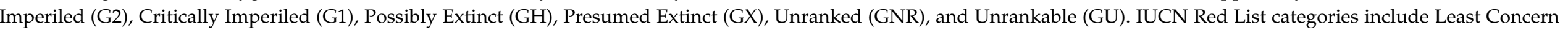

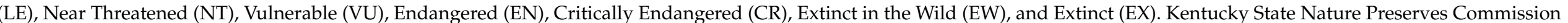

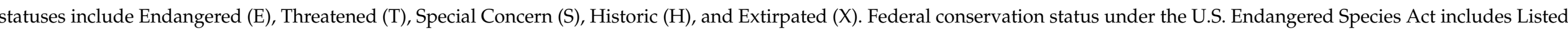
Endangered (LE) and Listed Threatened (LT).

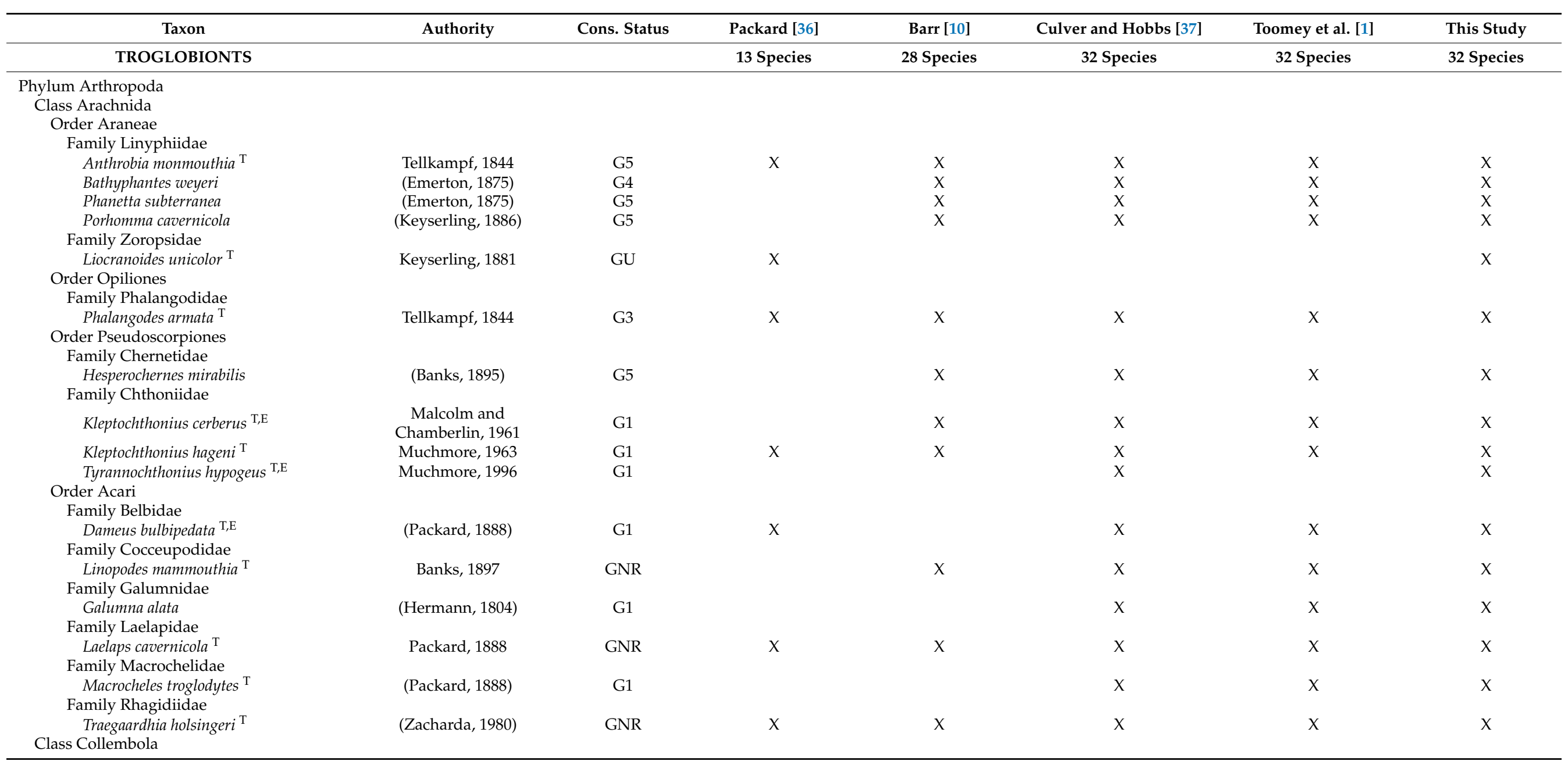


Table 1. Cont.

\begin{tabular}{|c|c|c|c|c|c|c|c|}
\hline Taxon & Authority & Cons. Status & Packard [36] & Barr [10] & Culver and Hobbs [37] & Toomey et al. [1] & This Study \\
\hline TROGLOBIONTS & & & 13 Species & 28 Species & 32 Species & 32 Species & 32 Species \\
\hline \multicolumn{8}{|l|}{$\begin{array}{l}\text { Order Entomobryomorpha } \\
\text { Family Entomobryidae }\end{array}$} \\
\hline Pseudosinella espanita $^{\mathrm{T}, \mathrm{E}}$ & $\begin{array}{l}\text { Christiansen and } \\
\text { Bellinger, } 1996\end{array}$ & G1 & & & $x$ & $x$ & $x$ \\
\hline \multicolumn{8}{|l|}{ Order Symphypleona } \\
\hline Pygmarrhopalites altus $\mathrm{T}, \mathrm{E}$ & (Christiansen, 1966) & G2 & & $x$ & $x$ & $x$ & $x$ \\
\hline \multicolumn{8}{|l|}{ Class Diplura } \\
\hline \multicolumn{7}{|l|}{ Family Campodeidae } & $x$ \\
\hline $\begin{array}{l}\text { Class Diplopoda } \\
\text { Order Chordeumatida }\end{array}$ & & & & & & & \\
\hline Family Macrosternodesmidae & & & & & & & \\
\hline $\begin{array}{l}\text { Chaetaspis fragilis }{ }^{\mathrm{T}} \\
\text { Class Insecta }\end{array}$ & (Loomis, 1943) & GNR & & $x$ & $x$ & $x$ & $x$ \\
\hline Order Coleoptera & \multicolumn{7}{|c|}{ Class Insecta } \\
\hline \multicolumn{8}{|l|}{ Family Carabidae } \\
\hline Neaphaenops tellkampfi ${ }^{\mathrm{T}}$ & (Erichson, 1844) & G3 & $x$ & $x$ & $x$ & $x$ & $x$ \\
\hline Pseudanophthalmus audax & (Horn, 1883) & G1 & & $\mathrm{x}$ & $\mathrm{x}$ & $x$ & $\mathrm{x}$ \\
\hline Pseudanophthalmus inexpectatus $\mathrm{T}, \mathrm{E}$ & Barr, 1959 & G1 & & $\mathrm{x}$ & $\mathrm{x}$ & $\mathrm{x}$ & $\mathrm{x}$ \\
\hline Pseudanophthalmus menetriesi $^{\mathrm{T}}$ & (Motschulsky, 1862) & G3 & $\mathrm{x}$ & $\mathrm{x}$ & $x$ & $x$ & $x$ \\
\hline Pseudanophthalmus pubescens & (Horn, 1868) & G3 & & $\mathrm{x}$ & $x$ & $x$ & $x$ \\
\hline Pseudanophthalmus striatus ${ }^{\mathrm{T}}$ & (Motschulsky, 1862) & G2 & $x$ & $x$ & $x$ & $x$ & $x$ \\
\hline \multicolumn{8}{|l|}{ Family Leiodidae } \\
\hline Ptomaphagus hirtus ${ }^{\mathrm{T}}$ & (Tellkampf, 1844) & G4 & $x$ & $x$ & $x$ & $x$ & $x$ \\
\hline $\begin{array}{c}\text { Family Staphylinidae } \\
\text { Batrisodes henroti }\end{array}$ & Park, 1956 & G2 & & $x$ & $x$ & $x$ & $x$ \\
\hline \multicolumn{8}{|l|}{ Order Diptera } \\
\hline Megaselia cavernicola & (Brues, 1906) & GNR & & & & $x$ & \\
\hline Family Sphaeroceridae & & & & & & & \\
\hline Spelobia tenebrarum & (Aldrich, 1897) & G5 & & & $x$ & $x$ & $x$ \\
\hline Order Psocodea & & & & & & & \\
\hline Family Psyllipsocidae & & & & & & & \\
\hline Psyllipsocus ramburii & Selys-Longchamps, 1872 & GNR & & $\mathrm{x}$ & & & \\
\hline
\end{tabular}


Table 1. Cont.

\begin{tabular}{|c|c|c|c|c|c|c|c|}
\hline Taxon & Authority & Cons. Status & Packard [36] & Barr [10] & Culver and Hobbs [37] & Toomey et al. [1] & This Study \\
\hline TROGLOBIONTS & & & 13 Species & 28 Species & 32 Species & 32 Species & 32 Species \\
\hline \multicolumn{8}{|l|}{ Phylum Mollusca } \\
\hline \multicolumn{8}{|l|}{ Class Gastropoda } \\
\hline \multicolumn{8}{|l|}{ Order Basommatophora } \\
\hline \multicolumn{8}{|l|}{ Family Carychiidae } \\
\hline Carychium stygium $^{\mathrm{T}}$ & Call, 1897 & G3 & & $x$ & $x$ & $x$ & $x$ \\
\hline \multicolumn{8}{|l|}{ Order Stylommatophora } \\
\hline \multicolumn{8}{|l|}{ Family Helicodiscidae } \\
\hline Helicodiscus hadenoecus & Hubricht, 1962 & G3 & & $\mathrm{x}$ & & & \\
\hline \multicolumn{8}{|l|}{ Family Zonitidae } \\
\hline Glyphyalinia specus & Hubricht, 1965 & G4 & & $x$ & $x$ & $x$ & $x$ \\
\hline STYGOBIONTS & & & 6 species & 16 species & 16 species & 18 species & 17 species \\
\hline \multicolumn{8}{|l|}{ Phylum Platyhelminthes } \\
\hline \multicolumn{8}{|l|}{ Class Turbellaria } \\
\hline \multicolumn{8}{|l|}{ Order Tricladida } \\
\hline \multicolumn{8}{|l|}{ Family Kenkiidae } \\
\hline Sphalloplana buchanani ${ }^{\mathrm{T}}$ & (Hyman, 1937) & G1 & & $x$ & $\mathrm{x}$ & $x$ & $\mathrm{x}$ \\
\hline Sphalloplana percoeca ${ }^{\mathrm{T}}$ & (Packard, 1879) & G5 & $x$ & $x$ & $x$ & $x$ & $x$ \\
\hline \multicolumn{8}{|l|}{ Phylum Arthropoda } \\
\hline \multicolumn{8}{|l|}{ Order Amphipoda } \\
\hline \multicolumn{8}{|l|}{ Crangonyctidae } \\
\hline Crangonyx barri $^{\mathrm{T}}$ & $\begin{array}{c}\text { Zhang and } \\
\text { Holsinger, } 2003\end{array}$ & G5 & & $x$ & $x$ & $x$ & $x$ \\
\hline Stygobromus exilis & Hubricht, 1943 & G5 & & $x$ & $x$ & $x$ & $x$ \\
\hline Stygobromus vitreus $\mathrm{T}^{\mathrm{T}}$ & Cope, 1872 & G4; $S$ & $\mathrm{x}$ & $\mathrm{x}$ & $\mathrm{x}$ & $\mathrm{x}$ & $\mathrm{x}$ \\
\hline \multicolumn{8}{|l|}{ Order Decapoda } \\
\hline \multicolumn{8}{|l|}{ Family Atyidae } \\
\hline Palaemonias ganter ${ }^{\mathrm{T}}$ & Hay, 1901 & G1; VU; E; LE & & $x$ & $x$ & $x$ & $x$ \\
\hline \multicolumn{8}{|l|}{ Family Cambaridae } \\
\hline Orconectes pellucidus ${ }^{\mathrm{T}}$ & (Tellkampf, 1844) & G4; LC; & $x$ & $x$ & $x$ & $x$ & $x$ \\
\hline \multicolumn{8}{|l|}{$\begin{array}{l}\text { Order Isopoda } \\
\text { Orctils }\end{array}$} \\
\hline \multicolumn{8}{|l|}{ Family Asellidae } \\
\hline Caecidotea bicrenata & $\begin{array}{l}\text { Lewis and } \\
\text { Bewman } 1981\end{array}$ & G5 & & & & $x$ & $x$ \\
\hline Caecidotea stygia ${ }^{\mathrm{T}}$ & Packard, 1871 & G5 & $x$ & $x$ & $x$ & $x$ & $x$ \\
\hline Class Maxillopoda & & & & & & & \\
\hline Order Cyclopoida & & & & & & & \\
\hline
\end{tabular}


Table 1. Cont.

\begin{tabular}{|c|c|c|c|c|c|c|c|}
\hline Taxon & Authority & Cons. Status & Packard [36] & Barr [10] & Culver and Hobbs [37] & Toomey et al. [1] & This Study \\
\hline TROGLOBIONTS & & & 13 Species & 28 Species & 32 Species & 32 Species & 32 Species \\
\hline $\begin{array}{l}\text { Family Cyclopidae } \\
\text { Megacyclops donnaldsoni } \\
\text { Order Harpacticoida }\end{array}$ & (Chappuis, 1929) & G3 & & $\mathrm{x}$ & $x$ & $\mathrm{x}$ & $\mathrm{x}$ \\
\hline $\begin{array}{l}\text { Family Canthocamptidae } \\
\text { Attheyella pilosa } a^{\mathrm{T}} \\
\text { Bryocamptus morrisoni }\end{array}$ & $\begin{array}{l}\text { Chappuis, } 1929 \\
\text { (Chappuis, 1928) }\end{array}$ & $\begin{array}{l}\text { GNR } \\
\text { G3 }\end{array}$ & & $\begin{array}{l}X \\
X\end{array}$ & $\begin{array}{l}x \\
X\end{array}$ & $\begin{array}{l}x \\
X\end{array}$ & $\mathrm{x}$ \\
\hline $\begin{array}{l}\text { Order Siphonostomatoida } \\
\text { Family Lernaeopodidae }\end{array}$ & (2) & $C 1$ & & & & v & $Y$ \\
\hline $\begin{array}{l}\text { Order Podocopida } \\
\text { Family Entocytheridae }\end{array}$ & & & & & & & \\
\hline $\begin{array}{l}\text { Sagittocythere barri } \\
\text { Sagittocythere stygia } \mathrm{T}, \mathrm{E}\end{array}$ & $\begin{array}{l}\text { (Hart and Hobbs, 1961) } \\
\text { Hart and Hart, } 1966\end{array}$ & $\begin{array}{l}\text { G5 } \\
\text { G1 }\end{array}$ & & $\begin{array}{l}X \\
X\end{array}$ & $\begin{array}{l}X \\
X\end{array}$ & $\begin{array}{l}X \\
X\end{array}$ & $\begin{array}{l}X \\
X\end{array}$ \\
\hline $\begin{array}{l}\text { Phylum Mollusca } \\
\text { Class Gastropoda } \\
\text { Order Neotaenioglossa } \\
\text { Family Hydrobiidae }\end{array}$ & & & & & & & \\
\hline $\begin{array}{l}\text { Antroselates spiralis }{ }^{\mathrm{T}} \\
\text { Phylum Chordata } \\
\text { Class Actinopterygii }\end{array}$ & Hubricht, 1963 & G3 & & $x$ & $x$ & $x$ & $x$ \\
\hline $\begin{array}{l}\text { Order Percopsiformes } \\
\text { Family Amblyopsidae }\end{array}$ & & & & & & & \\
\hline Amblyopsis spelaea $\mathrm{T}^{\mathrm{T}}$ & DeKay, 1842 & G2; NT; S & $\mathrm{x}$ & $\mathrm{x}$ & $\mathrm{x}$ & $\mathrm{x}$ & $\mathrm{x}$ \\
\hline Typhlichthys subterraneus & Girard, 1859 & G4; NT; S & $\mathrm{X}$ & $x$ & $x$ & $x$ & $\mathrm{x}$ \\
\hline
\end{tabular}

${ }^{\mathrm{T}}$ Type locality in Mammoth Cave National Park; ${ }^{\mathrm{E}}$ Mammoth Cave National Park endemic. 
Our list of cave-limited fauna includes 49 species, with 32 troglobionts and 17 stygobionts (Table 1; Figure 2). Both Culver and Hobbs [37] and Toomey et al. [1] included the snail Helicodiscus punctatellus and copepod Atteyella pilosa in their respective lists of cave-limited taxa. Helicodiscus punctatellus is known from surface collections [64]. Atteyella pilosa is a facultative associate of several species of surface and cave-limited crayfishes and is also known from surface collections [65]. Culver and Hobbs [37] did not include the isopod Caecidotea bicrenata, which was included in our list and that of Toomey et al. [1]. Lewis [66] reported several collections of C. bicrenata from the Mammoth Cave System where it predominately occurs in lower-level aquatic habitats. Toomey et al. [1] included the phorid fly Megaselia cavernicola in their list of cave-limited taxa. Megaselia cavernicola is a widely occurring species in caves on eastern North America that lacks obvious troglomorphic characters, is known from surface collections [67], and has been treated as a troglophile (i.e., non-obligate) by most past authors (e.g., [68,69]).
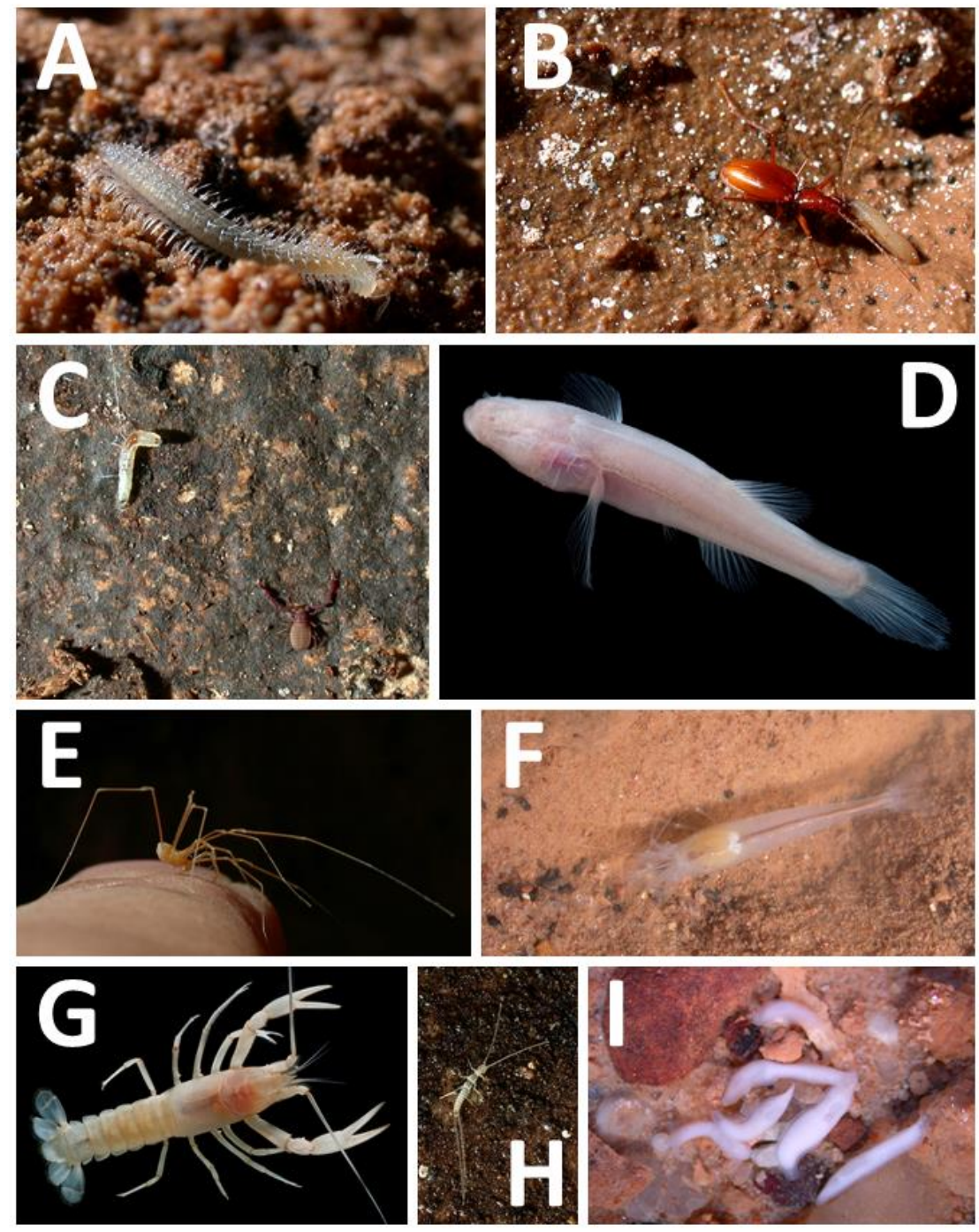

Figure 2. Representative cave-limited fauna from the Mammoth Cave System, Kentucky, USA: (A) Scoterpes copei (photo by Rickard A. Olson); (B) Neaphaenops tellkampfi feeding on the egg of the Hadenoecus subterraneus (photo by Rickard A. Olson); (C) Hesperochernes mirabilis with Macrocera nobilis larva (photo by Rickard A. Olson); (D) Amblyopsis spelaea (photo by Dante B. Fenolio); (E) Phalangodes armata (photo by Rickard A. Olson); (F) Palaemonias ganteri (photo by Rickard A. Olson); (G)—Orconectes pellucidus (photo by Dante B. Fenolio); (H) Litocampa cookei (photo by Rickard A. Olson); (I)—Sphalloplana buchanani (photo by Rickard A. Olson). 
Mammoth Cave is the type locality for 33 cave-limited species (Table 1). Seven species are endemic to the Mammoth Cave system and other smaller caves in Mammoth Cave National Park (Table 1).

\subsection{Terrestrial Fauna}

Two troglobiotic snails have been documented in the Mammoth Cave System. Carychium stygium is found in association with cricket guano and is the most common of the two species [37]. Weigand et al. [70,71] suggest C. stygium may be an ecotype of the troglophile C. exile, as C. stygium shows limited mitochondrial COI sequence divergence from and is nested within a clade containing $C$. clappi and C. exile. However, this inference is based on a single locus and only two populations of $C$. stygium were included in analyses. Alternative hypotheses such as incomplete lineage sorting and mitochondrial introgression cannot be ruled out at present and warrant study. Regardless, these studies suggest that it is likely that C. stygium has recently colonized caves. Glyphyalinia specus is a wide-ranging snail known from 27 occurrences in five states [72]. Significant publications include Call [28], Hubricht [49,50,52,53], Barr [10], Poulson et al. [73], Dourson [74], Poulson [62], and Gladstone et al. [72].

Troglobiotic spiders documented in the Mammoth Cave System include four linyphiids and one zoropsid. All four linyphiids have broad distributions in caves of the eastern United States [75]. Bathyphantes weyeri is predominantly known from caves but has rarely been collected from surface habitats in Canada [75-77]. Holsinger et al. [78] hypothesized that the species may be troglobiotic in the southern parts of its range and troglophilic in the northern areas. Moreover, B. weyeri may represent a species complex. Most authors, including herein, still treat this species as a troglobiont $[1,37,76,78,79]$. Liocranoides unicolor was described by Keyserling [80] from Mammoth Cave. This species is pale in coloration but does not possess other troglomorphic characters [81]. Significant publications include Packard [29,32,33,36], Emerton [82], Hubbard [83], Keyserling [80], Call [28], Mcindoo [84], Berland [85], Bailey [44], Barr [10], Poulson and Culver [86], Poulson [62,87], Platnick [81], and Miller [75].

A single troglobiotic opilionid (Phalangodes armata) is known from several areas in the Mammoth Cave System. Significant publications include Tellkampf [20,21], Packard [29,36], Hubbard [83], Call [28], Bailey [44], Goodnight and Goodnight [88], Barr [10], Poulson and Culver [86], Hedin and Thomas [89], and Poulson [62].

Four troglobiotic pseudoscorpions occur in the Mammoth Cave System. Hesperochernes mirabilis is a widely distributed species most abundant near entrances. It is often observed in and near rodent (Neotoma and Peromyscus sp.) nests, which may facilitate phoretic dispersal. The other three species are thought to be associated with deep cave habitats. Kleptochthonius cerberus was described from White's Cave in Mammoth Cave National Park [90] and has to date, only been found there. Kleptochthonius hageni was described from Mammoth Dome in Mammoth Cave [91]. Kleptochthonius cereberus is thought to be endemic to Mammoth Cave National Park. Kleptochthonius hageni is reported to occur in the Mammoth Cave System and possibly some nearby caves not on the park (C.D.R. Stephen, pers. comm.). Tyrannochthonius hypogeus is a small, eyeless species with attenuated appendages first collected from log litter in Bruce Hollow [92]. Muchmore [92] considered this species to be cave adapted and associated with the Mammoth Cave fauna. Notable publications include Hubbard [83], Packard [36], Banks [93], Malcolm and Chamberlin [90], Muchmore [91,92], and Barr [10].

The troglobiotic mite fauna is particularly diverse with six species but has been little studied since their descriptions [37]. Notable publications include Packard [36], Call [28], Vitzthum [94], Bailey [44], Holsinger [95], Barr [10], and Zacharda [96].

Two troglobiotic millipedes have been documented in the Mammoth Cave System. Scoterpes copei is a common trichopetalid distributed throughout the cave system where it can be found in moist habitats with organic matter (rotting wood, debris, and cricket guano). Chaetaspis fragilis is a small polydesmid infrequently encountered in the Mammoth Cave 
System but more common in White Cave, Mammoth Cave National Park [10]. Significant publications include Packard [29,36], Cope [97], Hubbard [83], Loomis [98], Barr [10], Poulson and Culver [86], Poulson et al. [73], Shear [99], and Poulson [62].

Although more than 10 species of collembolans (i.e., springtails) have been documented in the Mammoth Cave System [10], just two taxa are considered troglobionts and both are endemic to the cave system. Pygmarrhopalites altus was described by Christiansen [100] from Eyeless Fish Trail in the Unkown Cave section of Mammoth Cave. Pseudosinella espanita was described by Christiansen and Bellinger [101] from Styx River near Charon's Cascade in Mammoth Cave. Notably absent from the fauna of the Mammoth Cave System are P. hirsuta and Sinella cavernarum, which have broad distributions that include the Western Pennyroyal Karst of nearby Barren County, Kentucky [102]. Barr [10] reported two undescribed collembolans as potential troglobionts from Mammoth Cave: Willemia sp. have been collected from rotting boards in the Roaring River section. This genus includes several edaphic species, but no troglobionts are known to date and it is unlikely that this taxon represents a true troglobiont. Onychiurus sp. also have been collected from Mammoth Cave. Four described species in this genus are considered troglobionts in caves of the eastern United States. Additional study is needed on the collembolans of the Mammoth Cave System. Significant publications include Packard [36], Call [28], Christiansen [97,103-105], Barr [10], Poulson and Culver [86], Christiansen and Bellinger [101], and Poulson [62].

A single troglobiotic dipluran occurs in the Mammoth Cave System. Litocampa cookei has the largest distribution of any troglobiotic dipluran in the United States [106] but may represent a cryptic species complex. It was described from Mammoth Cave [29]. Notable publications include Packard [29,30,36], Hubbard [83], Silvestri [107,108], Conde [109], Barr [10], Poulson and Culver [86], Ferguson [106,110], and Poulson [62].

The troglobiotic beetle fauna is the most well known and studied of all taxonomic groups in the Mammoth Cave System. Eight species have been documented, namely six carabids, one leiodid, and one staphylinid species. Neaphaenops tellkampfii is the largest troglobiotic carabid species in Mammoth Cave and is also the first troglobiotic trechine beetle discovered in North America [111]. It was described from Mammoth Cave [112]. This species is found in silty habitats, where it feeds mostly on the eggs of the cave cricket Hadenoecus subterraneus [111,113]. Five species in the genus Pseudanophthalmus occur in a variety of habitats throughout the Mammoth Cave System. Three species were described from Mammoth Cave and one species (P. inexpectatus) is endemic to MCNP. All six species are blind and wingless. In some locations in the cave system, all six carabid species can be found but appear to have different microhabitat preferences and can be readily distinguished morphologically [59,60,113]. Ptomaphagus hirtus is an abundant small carrion beetle that is becoming an important model for studying the genetics of circadian rhythms [114,115]. Batrisodes henroti is a small rove beetle that has been infrequently collected in the Mammoth Cave System. Relevant publications include Erichson [112], Tellkampf [20,21], Von Motschulsky [26,27], Horn [116,117], Packard [29,31,34,36], Hubbard [83], Jeannel [118-121], Valentine [122,123], Hatch [124], Jeannel and Henrot [54], Park [125-127], Barr [10,55-60,128-131], Poulson and Culver [86], Barr and Kuehne [132], Peck [133-137], Kane et al. [138], Norton et al. [139], Kane and Poulson [140], Laing et al. [141], Giuseffi et al. [142], Kane and Ryan [143], Barr and Holsinger [144], Kane and Brunner [145], Poulson et al. [73], Friedrich et al. [115], Friedrich [114], Helf [146], Poulson [62], and Leray et al. [147].

The only other troglobiotic insect documented from Mammoth Cave is the dipteran Spelobia tenebrarum, a widely distributed species in caves of eastern North America [148]. Notable publications include Barr [10], Marshall and Peck [148], and Poulson [62].

\subsection{Aquatic Fauna}

Two cave flatworms occur in and were described from the Mammoth Cave System. Sphalloplana percoeca occurs primarily in epikarst-fed drip pools in upper-level passages, 
while S. buchanani is associated with stream gravels [37]. Significant publications on cave flatworms include Packard [29,36], de Beauchamp [149], Buchanan [45], Hyman [150], Barr [10], Carpenter [151,152], Barr and Kuehne [132], Kenk [153], Lewis [66], Pearson and Boston [154], and Helf and Olson [63].

A single groundwater snail has been documented in the Mammoth Cave System. Antroselates spiralis occurs in base-level streams in cave system. It was described from Echo River Spring, a major drain of the Mammoth Cave System. Notable publications include Hubricht [51], Barr [10], Barr and Kuehne [132], Hershler and Hubricht [155], Lewis [66], Pearson and Boston [154], and Helf and Olson [63].

The copepods of the Mammoth Cave System have not been well studied [37]. Three stygobionts have been documented-Megacyclops donnaldsoni, Bryocamptus morrisoni, and Cauloxenus stygius. Cauloxenus stygius is an ectoparasite of the cavefish Amblyopsis spelaea [156]. Notable publications include Cope [97], Kofoid [157], Chappuis [158], Barr [10], Barr and Kuehne [132], Whitman [159], Lewis [160], Niemiller and Poulson [156], and Helf and Olson [63].

Two ostracods are ectocommensals primarily of the stygobiotic crayfish Orconectes pellucidus-Sagittocythere barri and S. stygia. Sagittocythere stygia was described from River Styx in Mammoth Cave. Significant publications include Kofoid [157], Klie [161], Hart and Hobbs [162], Hart and Hart [163], Barr [10], Barr and Kuehne [132], Hart and Hart [164], and Helf and Olson [63].

Isopods are represented by two aquatic stygobionts-Caecidotea stygia and C. bicrenata. Caecidotea stygia was described from Mammoth Cave by Packard [29] and is more abundant in upper to mid-levels of the cave system, whereas C. bicrenata is more common in low to mid-levels [66]. Significant publications include Packard [29,35,36], Hubbard [79], Garman [165], Hay [166], Giovannoli [167], Dearolf [47], Chappuis [168], Barr [10], Barr and Kuehne [132], Lewis and Bowman [169], Lewis [66], Helf and Olson [63], and Helf et al. [170].

Three species of stygobiotic amphipods have been reported from the Mammoth Cave System. Stygobromus vitreus is more common in upper levels of the cave system, while S. exilis is more common in low to mid-levels [66,132]. Stygobromus vitreus was described from Richardson Spring within Mammoth Cave. Cathedral Domes in Mammoth Cave is the type locality of Crangonyx barri, an inhabitant of small cave streams and drip pools [171]. Signification publications include Cope [97], Packard [36], Giovannoli [167], Hubricht [48], Barr [10], Barr and Kuehne [132], Holsinger [172], Lewis [66], Zhang [173], Zhang and Holsinger [171], Helf and Olson [63], and Helf et al. [170].

Two stygobiotic decapods occur in the Mammoth Cave System. Palaemonias ganteri is a federally endangered atyid shrimp found in slow-flowing base-level streams of eleven groundwater basins in the Mammoth Cave System ([174]; updated by R. Toomey with new data). Significant publications on P. ganteri include Hay [166], Fage [175], Giovanolli [167], Barr [10], Barr and Kuehne [132], Hobbs et al. [176], Holsinger and Leitheuser [177-179], Lisowski [180,181], Lisowski and Poulson [182], Leitheuser and Holsinger [183], Leitheuser et al. [184,185], Lewis [66], USFWS [174,186], Pearson and Boston [154], Pearson and Jones [187], Cooper and Cooper [188], Helf and Olson [63], and Stump [189]. Orconectes pellucidus was described from Mammoth Cave and is the only stygobiotic crayfish in the cave system. While O. pellucidus is a ubiquitous stygobiont in the Mammoth Cave System, it is more abundant in mid- and base-level streams and pools. Notable publications include Tellkampf [20,21], Hagen [190,191], Packard [29,36], Cope [97], Garman [192], Fage [175], Bailey [44], Park et al. [193], Rhoades [194], Hobbs and Barr [195,196], Brown [197], Wolfe and Cornwell [198], Barr [10], Hobbs et al. [176], Pearson and Boston [154], Pearson and Jones [187], Compson [199], Taylor and Schuster [200], Helf and Olson [63], and Helf et al. [170].

The only cave-limited vertebrates known from the Mammoth Cave System are the amblyopsid cavefishes Amblyopsis spelaea and Typhlichthys subterraneus. Amblyopsis spelaea was described from River Styx in Mammoth Cave by Dekay [13] and represents the 
first cave-adapted fish formally described $[156,201]$. Mammoth Cave is one of only a handful of cave systems globally with two or more syntopic cavefish species [156,201]. Typhlichthys subterraneus are more abundant in upstream sections of streams that drain vertical shafts, whereas $A$. spelaea are more common in deeper pools at base level $[61,156]$; both are top predators. It remains unclear whether $A$. spelaea outcompetes T. subterraneus in base-level habitats. Significant publications on cavefishes of Mammoth Cave include Davidson [202], DeKay [13], Wyman [14-19], Thompson [203], Tellkampf [21,22], Agassiz [23-25], Girard [204], Putnam [38], Packard [36], Eigenmann [39-42], Bailey [44], Woods and Inger [205], Poulson [61,206-208], Barr and Kuehne [209], Rosen [210], Barr [10], Poulson and White [211], Barr and Kuehne [132], Clay [212], Swofford et al. [213], Lisowski and Poulson [182], Swofford [214], Burr and Warren [215], Lewis [66,160,216], Keith [217], Branson [218], Pearson and Boston [154], Pearson and Jones [187], Romero [219], Romero and Bennis [220], Compson [199], Proudlove [201], Niemiller and Poulson [156], Niemiller [221], Niemiller and Fitzpatrick [222], Niemiller et al. [223], Helf and Olson [63], Helf et al. [170], and Hart et al. [224].

\section{Discussion}

The Mammoth Cave obligate cave fauna is exceptionally rich with 49 troglobionts and stygobionts, making it one of the most diverse systems globally $[37,225,226]$. The terrestrial fauna is particularly diverse-tied for the third richest cave system in the world behind the Postojna Planina Cave System (36 species) in Slovenia and Cueva de Felipe Revention (34 species) in the Canary Islands [226]. With respect to stygobiotic fauna, the Mammoth Cave System ranks second in North America behind San Marcos Artesian Well in San Marcos, Texas (55 taxa, 39 described and 16 undescribed; [227]).

Several hypotheses have been proposed $[10,61,127,224,228]$ to explain the high species richness in the Mammoth Cave System (recently reviewed in [37]). First, high species richness in the Mammoth Cave System may reflect the long history of more intensive sampling and study compared to other cave systems in the region [37]. While sampling intensity and bias may partially explain the high species richness at Mammoth Cave, several other biogeographical hypotheses warrant mention. The Mammoth Cave System is developed within a thick, continuous karst exposure over a large area in the Interior Low Plateau, which supports larger and more stable population sizes, more complex communities, and greater dispersal potential $[113,129,130]$. Moreover, the Mammoth Cave System is located at an intersection of hypothesized dispersal routes for cave-limited species from other karst areas, such as the Pennyroyal Karst Plain, Cumberland Saddle, and Bluegrass Region, and its cave fauna includes not only endemic species but also taxa also found in these adjacent regions $[10,37,66,130]$. The Mammoth Cave System lies within a hypothesized ridge of high troglobiont diversity found in temperate North America and Europe identified by Culver et al. [228]. This ridge corresponds to a general region of high surface primary productivity, which provides higher levels of allochthonous input into cave systems [228]. Mammoth Cave is noted for having high levels of allochthonous productivity but also chemoautotrophic productivity $[37,63,229]$. However, whether chemosynthesis subsidizes troglobiont communities or contributes significantly to the high troglobiont diversity found in the Mammoth Cave System remains speculative, as it is not well supported by empirical evidence.

The obligate fauna of the Mammoth Cave System is diverse and includes 39 cavelimited species (18 troglobionts an 11 stygobionts) of conservation concern, highlighted by the federally endangered cave shrimp Palaemonias ganteri. Most of these species are at an elevated risk of extinction due to their limited distributions and/or are known from few occurrences. For example, the cave pseudoscorpion Tyrannochthonius hypogeus is known from just two specimens collected from a single locality [92]. Cave-limited fauna face many threats, such as habitat loss and degradation, groundwater overexploitation and contamination, and climate change $[230,231]$. 
Although much of the Mammoth Cave System lies within the boundaries of Mammoth Cave National Park, the cave system is not immune to direct and indirect threats to its biodiversity, particularly those stressors that originate from outside of the park, such as industrial and tourism development, oil and gas drilling, runoff from agriculture, residential areas, and highways, and emergent diseases [63,232-236]. For example, sewage from the town of Park City was previously known to drain into the headwaters of the Echo River basin potentially impacted the stygobiotic fauna [130], including Typhlichthys subterraneus, Amblyopsis spelaea, Palaemonias ganteri, Orconectes pellucidus, and Antroselates spiralis. A hydrocarbon spill along Interstate 65 was responsible for a significant die-off of aquatic cave life [232,236]. Flow reversals and back-flooding from the Green River into cave springs also may transport sediment, potential contaminants, pathogens, and invasive aquatic species into base level streams in the Mammoth Cave System [237-239].

Great potential still exists to discover new taxa and add to the list of obligate species at Mammoth Cave. Two potentially cave-limited springtails that we do not include in our checklist (Willemia sp. and Onychiurus sp.) are known from Mammoth Cave and have not been identified to species $[1,10]$. Terrestrial woodlice are notably absent from the troglobiotic fauna of Mammoth Cave and may be discovered in the future. Seven troglobiotic trichoniscids (Isopoda, family Trichoniscidae) are known caves of the Interior Low Plateau and Appalachians karst regions [240], including Miktoniscus barri known from several caves of Indiana and Kentucky [241]. A troglophilic species, Miktoniscus mammothensis, occurs in cave and surface habitats at MCNP [242]. Other taxonomic groups have not been particularly well studied in the Mammoth Cave System, such as flatworms, copepods, springtails, and mites. More intensive work on these groups may uncover additional taxa. With more than $651 \mathrm{~km}$ of passage, much of the Mammoth Cave System has not been comprehensively bioinventoried, and some habitats, such as epikarst, have been disproportionately under-sampled and may harbor undescribed taxa [37]. In addition, over 500 other caves occur in MCNP, including several biologically rich sites, such as White and Great Onyx caves. These cave systems also may harbor undocumented diversity. Finally, few genetic studies to date have incorporated samples from the Mammoth Cave System. Comprehensive sampling within the Mammoth Cave System has the potential to uncover cryptic diversity in some taxonomic groups, which is an increasingly common discovery of genetic and phylogenetic studies in cave-limited taxa [223,243-245].

Author Contributions: Conceptualization, M.L.N.; methodology and analysis, M.L.N.; data acquisition, M.L.N., K.H. and R.S.T.; original draft preparation, M.L.N.; review and editing, M.L.N., K.H. and R.S.T. All authors have read and agreed to the published version of the manuscript.

Funding: M.L.N. was supported by the National Science Foundation (award No. 2047939).

Institutional Review Board Statement: Not applicable.

Informed Consent Statement: Not applicable.

Data Availability Statement: No new data were created or analyzed in this manuscript. Data sharing is not applicable for this manuscript.

Acknowledgments: We thank Dante B. Fenolio and Rickard A. Olson for providing photographs. The views presented herein are those of the authors and do not necessarily represent those of the National Park Service.

Conflicts of Interest: The authors declare no conflict of interest.

\section{References}

1. Toomey, R.S.; Hobbs, H.H., III; Olson, R.A. An orientation to Mammoth Cave and this volume. In Mammoth Cave: A Human and Natural History, Cave and Karst Systems of the World; Springer: Berlin/Heidelberg, Germany, 2017; pp. 1-28.

2. Miotke, F.D.; Palmer, A.N. Genetic Relationship between Cave Land-Forms in the Mammoth Cave National Park Area; Boehler Verlag: Wuerzburg, Germany, 1972.

3. Palmer, A.N. A Geological Guide to Mammoth Cave National Park; Zephyrus Press: Teaneck, NJ, USA, 1981.

4. Palmer, A.N. Cave Geology; Cave Books: Dayton, OH, USA, 2007. 
5. Palmer, A.N. Geology of Mammoth Cave. In Mammoth Cave: A Human and Natural History, Cave and Karst Systems of the World; Springer: Berlin/Heidelberg, Germany, 2017; pp. 97-110.

6. Palmer, A.N. Geologic history of Mammoth Cave. In Mammoth Cave: A Human and Natural History, Cave and Karst Systems of the World; Springer: Berlin/Heidelberg, Germany, 2017; pp. 111-121.

7. Quinlan, J.F.; Ewers, R.O. Hydrogeology of the Mammoth Cave region, Kentucky. In GSA Cincinnati 1981 Field Trip Guidebook 3; American Geological Institute: Falls Church, VA, USA, 1981; pp. 457-506.

8. Glennon, A.; Groves, C. An examination of perennial stream drainage patterns within the Mammoth Cave watershed, Kentucky. J. Cave Karst Stud. 2002, 64, 82-91.

9. Granger, D.E.; Fabel, D.; Palmer, A.N. Pliocene-Pleistocene incision of the Green River, Kentucky, determined from radioactive decay of cosmogenic ${ }^{26} \mathrm{Al}$ and ${ }^{10} \mathrm{Be}$ in Mammoth Cave sediments. Geo. Soc. Am. Bull. 2001, 113, 825-836. [CrossRef]

10. Barr, T.C., Jr. Ecological studies in the Mammoth Cave System of Kentucky I: The biota. Int. J. Speleol. 1968, 3, 147-204. [CrossRef]

11. Rafinesque, C. The caves of Kentucky. Atl. J. 1832, 1, 27-30.

12. Darwin, C. On the Origin of Species by Means of Natural Slection, or the Preservation of Favoured Races in the Struggle for Life, 1st ed.; John Murray: London, UK, 1859.

13. DeKay, J.E. Zoology of New York or the New York Fauna; Comprising Detailed Descriptions of All the Animals Hitherto Observed within the State of New York, with Brief Notices of Those Occasionally found Near Its Borders, and Accompanied by Appropriate Illustrations. Part IV, Fishes; W.\& A. White \& J. Visscher: Albany, NY, USA, 1842.

14. Wyman, J. Description of a blind-fish from a cave in Kentucky. Am. J. Sci. Arts 1843, 45, 94-96.

15. Wyman, J. Description of a blind-fish from a cave in Kentucky. Ann. Mag. Nat. Hist. 1843, 12, $298-299$.

16. Wyman, J. Account of dissections of the blind fishes (Amblyopsis spelaeus) from the Mammoth Cave, Kentucky. Proc. Boston Soc. Nat. Hist. 1851, 3, 349-375.

17. Wyman, J. The eyes and organs of hearing in Amblyopsis spelaeus. Proc. Boston Soc. Nat. Hist. 1854, 4, 149-151.

18. Wyman, J. On the eye and the organ of hearing in the blind fishes (Amblyopsis spelaeus DeKay) of the Mammoth Cave. Proc. Boston Soc. Nat. Hist. 1854, 4, 395-396.

19. Wyman, J. Notes and drawings of the rudimentary eyes, brain and tactile organs of Amblyopsis spelaeus, in Putnam (1872). Am. Nat. 1872, 6, 6-30.

20. Tellkampf, T.G. Ueber den blinden Fisch der Mammuth-Hohle in Kentucky, mit Bemerkungen ueber einige undere in dieser Hohle lebenden Thiere. Arch. Anat. Phys. Wiss. Med. 1844, 4, 381-394.

21. Tellkampf, T.G. Beschreibung einiger neuer in der Mammuth-Höhle in Kentucky aufgefundener Gattungen von Gliedertieren. Arch. Nat. 1844, 10, 318-322. [CrossRef]

22. Tellkampf, T.G. Memoirs on the blind-fishes and some other animals living in the Mammoth Cave in Kentucky. N. Y. J. Med. Collat. Sci. 1845, 5, 84-93.

23. Agassiz, J.L.R. Plan for an investigation of the embryology, anatomy and effect of light on the blind-fish of the Mammoth Cave, Amblyopsis spelaeus. Proc. Am. Acad. Arts Sci. 1847, 1, 1-180.

24. Agassiz, J.L.R. Observations of the blind fish of the Mammoth Cave. Am. J. Sci. Arts 1851, 11, 127-128.

25. Agassiz, J.L.R. Recent researches of Prof. Agassiz. Am. J. Sci. Arts 1853, 16, 134.

26. von Mutschulsky, T.V. Etudes Entomologiques, 3e Annee; Helsingfors, Finland, 1854.

27. von Mutschulsky, T.V. Etudes Entomologiques, 11e Annee; Dresden, Germany, 1862.

28. Call, R.E. Some notes on the flora and fauna of Mammoth Cave, Kentucky. Am. Nat. 1897, 31, 377-392. [CrossRef]

29. Packard, A.S. On the crustaceans and insects of the Mammoth Cave. Am. Nat. 1871, 5, 744-761.

30. Packard, A.S. Occurrence of Japan in the United States. Am. Nat. 1874, 8, 501-502.

31. Packard, A.S. Larvae of Anophthalmus and Adelops. Am. Nat. 1874, 8, 562-563.

32. Packard, A.S. The invertebrate cave fauna of Kentucky and adjoining states, Araneina. Am. Nat. 1875, 9, 271-278. [CrossRef]

33. Packard, A.S. Cave-inhabiting spiders. Am. Nat. 1875, 9, 663-664.

34. Packard, A.S. The cave-beetles of Kentucky. Am. Nat. 1876, 10, 282-287. [CrossRef]

35. Packard, A.S. On the structure of the brain of Asellus and the eyeless form Caecidotea. Am. Nat. 1885, $19,85-86$.

36. Packard, A.S. The cave fauna of North America, with remarks on the anatomy of the brain and origin of the blind species. Mem. Nat. Acad. Sci. USA 1888, 4, 1-156.

37. Culver, D.C.; Hobbs, H.H., III. Biodiversity of Mammoth Cave. In Mammoth Cave: A Human and Natural History, Cave and Karst Systems of the World; Hobbs, H.H., III, Olson, R.A., Winkler, E.G., Culver, D.C., Eds.; Springer: Berlin/Heidelberg, Germany, 2017; pp. 227-234.

38. Putnam, F.W. The blind fishes of the Mammoth Cave and their allies. Am. Nat. 1872, 6, 6-30. [CrossRef]

39. Eigenmann, C.H. The Amblyopsidae, the blind fish of America. Rep. Br. Assoc. Adv. Sci. 1897, 1897, $685-686$.

40. Eigenmann, C.H. The blind fishes of North America. Pop. Sci. Mon. 1899, 56, 473-486.

41. Eigenmann, C.H. Divergence and convergence in fishes. Biol. Lect. Mar. Biol. Lab. Woods Hole 1905, 8, 59-66. [CrossRef]

42. Eigenmann, C.H. Cave Vertebrates of America: A Study in Degenerative Evolution; Carnegie Institution of Washington: Washington, DC, USA, 1909.

43. Bolivar, C.; Jeannel, R. Campagne Speleologique dans I'Amerique du Nord en 1928. Biospeleologie LVI. Arch. Zool. Exp. Gen. 1931, 71, 293-499. 
44. Bailey, V. Cave life of Kentucky, mainly in the Mammoth Cave region. Am. Midl. Nat. 1933, 14, 385-635. [CrossRef]

45. Buchanan, J.W. Notes on an American cave flatworm, Sphalloplana percaeca (Packard). Ecology 1936, 17, 194-241. [CrossRef]

46. Park, O. Key to the more common adult animals of Mammoth and adjacent caves. In A Laboratory Introduction to Animal Ecology and Taxonomy; Park, O., Allee, W.C., Shelford, V.E., Eds.; University of Chicago Press: Chicago, IL, USA, 1939; pp. 118-124.

47. Dearolf, K. Report of a biological reconnaissance of the New Discovery in Mammoth Cave, Kentucky, January 7-11, 1941. Bul. Nat. Speleol. Soc. 1942, 4, 48-52.

48. Hubricht, L. Studies of the Nearctic freshwater Amphipoda, III. Notes on the freshwater Amphipoda of eastern United States, with description of ten new species. Am. Midl. Nat. 1943, 29, 683-712. [CrossRef]

49. Hubricht, L. The cave snail, Carychium stygium Call. Trans. Ky. Acad. Sci. 1960, 21, 35-38.

50. Hubricht, L. New species of Helicodiscus from the eastern United States. Nautilus 1962, 75, 102-107.

51. Hubricht, L. New species of Hydrobiidae. Nautilus 1963, 76, 138-140.

52. Hubricht, L. Land snails from the caves of Kentucky, Tennessee, and Alabama. Nat. Speleol. Soc. Bull. 1964, 26, 33-36.

53. Hubricht, L. Four new land snails from the southeastern United States. Nautilus 1965, 79, 4-7.

54. Jeannel, R.; Henrot, H. Les coleopteres cavernicoles de la region des Appalaches. I. La region des Appalaches (Jeannel), and II. Enumeration des grottes explorees (Henrot). Notes Biospel. 1949, 4, 11-36.

55. Barr, T.C., Jr. New cave beetles (Carabidae) from Tennessee and Kentucky. J. Tenn. Acad. Sci. 1959, 34, 5-30.

56. Barr, T.C., Jr. The male of Pseudanophthalmus audax (Coleoptera: Carabidae). Trans. Ky. Acad. Sci. 1959, $20,1-3$.

57. Barr, T.C., Jr. The blind beetles of Mammoth Cave, Kentucky. Am. Midl. Nat. 1962, 68, 278-284. [CrossRef]

58. Barr, T.C., Jr. Studies on the cavernicole Ptomaphagus of the United States (Coleoptera, Catopidae). Psyche 1963, 70, 50-58. [CrossRef]

59. Barr, T.C., Jr. Cave Carabidae (Coleoptera) of Mammoth Cave. Pysche 1966, 73, 284-287.

60. Barr, T.C., Jr. Cave Carabidae (Coleoptera) of Mammoth Cave, Part II. Pysche 1967, 74, 24-25.

61. Poulson, T.L. The Mammoth Cave ecosystem. In The Natural History of Biospeleology; Camacho, A., Ed.; Museo Nacional de Ciencias Naturales: Madrid, Spain, 1992; pp. 569-611.

62. Poulson, T.L. Terrestrial cave ecology of the Mammoth Cave region. In Mammoth Cave: A Human and Natural History, Cave and Karst Systems of the World; Hobbs, H.H., III, Olson, R.A., Winkler, E.G., Culver, D.C., Eds.; Springer: Berlin/Heidelberg, Germany, 2017; pp. 199-207.

63. Helf, K.L.; Olson, R.A. Subsurface aquatic ecology of Mammoth Cave. In Mammoth Cave: A Human and Natural History, Cave and Karst Systems of the World; Hobbs, H.H., III, Olson, R.A., Winkler, E.G., Culver, D.C., Eds.; Springer: Berlin/Heidelberg, Germany, 2017; pp. 209-226.

64. Coney, C.C.; Tarpley, W.A.; Bohannan, R. Ecological studies of land snails in the Hiawassee River Basin of Tennessee, U.S.A. Malacol. Rev. 1982, 15, 69-106.

65. Bowman, T.E.; Prins, R.; Morris, B.F. Notes on the harpacticoid copepods Attheyella pilosa and A. carolinensis, associates of crayfishes in the eastern United States. Proc. Biol. Soc. Wash. 1968, 81, 571-586.

66. Lewis, J.J. The Systematics, Zoogeography and Life History of the Troglobitic Isopods of the Interior Plateaus of the Eastern United States. Ph.D. Dissertation, University of Louisville, Louisville, KY, USA, 1988.

67. Borgmeier, T. Revision of the North American Phorid flies. Part III. The species of the genus Megaselia, subgenus Megaselia (Diptera, Phoridae): Studia Entomologica. Petropolis 1966, 8, 1-160.

68. Lewis, J.J. Bioinventory of Caves of the Cumberland Escarpment Area of Tennessee, Final Report; Tennessee Chapter of the Nature Conservancy: Nashville, TN, USA, 2005.

69. Zigler, K.S.; Niemiller, M.L.; Stephen, C.D.R.; Ayala, B.N.; Milne, M.A.; Gladstone, N.S.; Engel, A.S.; Jensen, J.B.; Camp, C.D.; Ozier, J.C.; et al. Biodiversity from caves and other subterranean habitats of Georgia, USA. J. Cave Karst Stud. 2020, 82, 125-167. [CrossRef]

70. Weigand, A.M.; Jochum, A.; Pfenninger, M.; Steinke, D.; Klussmann-Kolb, A. A new approach to an old conundrum-DNA barcoding sheds new light on phenotypic plasticity and morphological stasis in microsnails (Gastropoda, Pulmonata, Carychiidae). Mol. Ecol. Res. 2011, 11, 255-265. [CrossRef] [PubMed]

71. Weigand, A.M.; Jochum, A.; Slapnik, R.; Schnitzler, J.; Zarza, E.; Klussmann-Kolb, A. Evolution of microgastropods (Ellobioidea, Carychiidae): Integrating taxonomic, phylogenetic and evolutionary hypotheses. BMC Evol. Biol. 2013, 13, 18. [CrossRef]

72. Gladstone, N.S.; Carter, E.T.; McKinney, M.L.; Niemiller, M.L. Status and distribution of the cave-obligate land snails in the Appalachians and Interior Low Plateau of the eastern United States. Am. Malacol. Bull. 2018, 36, 62-78. [CrossRef]

73. Poulson, T.L.; Lavoie, K.H.; Helf, K. Long-term effects of weather on the cricket (Hadenoecus subterraneus, Orthoptera, Rhaphidophoridae) guano community in Mammoth Cave National Park. Am. Midl. Nat. 1995, 134, 226-236. [CrossRef]

74. Dourson, D.C. Kentucky's Land Snails and Their Ecological Communities; Goatslug Publications: Bakersville, NC, USA, 2010.

75. Miller, J.A. A redescription of Porrhomma cavernicola Keyserling (Araneae, Linyphiidae) with notes on Appalachian troglobites. J. Arachnol. 2005, 33, 426-439. [CrossRef]

76. Holsinger, J.R.; Culver, D.C. The invertebrate cave fauna of Virginia and a part of eastern Tennessee: Zoogeography and ecology. Brimleyana 1988, 14, 1-162.

77. Paquin, P.; Dupérré, N. Guide d'identifcation des Araignées (Araneae) du Québec. Fabreries Supplément 2003, 11, 1-251. 
78. Holsinger, J.R.; Culver, D.C.; Hubbard, D.A., Jr.; Orndorff, W.D.; Hobson, C.S. The invertebrate cave fauna of Virginia. Banisteria 2013, 42, 9-56.

79. Peck, S.B. A summary of diversity and distribution of the obligate cave-inhabiting faunas of the United States and Canada. J. Caves Karst Stud. 1998, 60, 18-26.

80. Keyserling, E.G. Neue Spinnen aus Amerika, III. Verh. zool.-bot. Ges. Wien 1881, 31, 269-314.

81. Platnick, N.I. A revision of the Appalachian spider genus Liocranoides (Araneae: Tengellidae). Amer. Mus. Nov. 1999, $3285,1-13$.

82. Emerton, J.H. Notes on spiders from caves in Kentucky and Indiana. Am. Nat. 1875, 9, 278-281. [CrossRef]

83. Hubbard, H.G. Two days collecting in the Mammoth Cave, with contributions to a study of its fauna. Am. Entomol. 1880, 3, 34-40.

84. McIndoo, N.E. Notes on some arachnids from Ohio valley caves. The Biol. Bull. 1911, 20, 183-186. [CrossRef]

85. Berland, L. Arachnides araneides (Biospeologica LVI) . Arch Zool. Exp. Gen. 1931, 71, 383-388.

86. Poulson, T.L.; Culver, D.C. Diversity in terrestrial cave communities. Ecology 1969, 50, 153-158. [CrossRef]

87. Poulson, T.L. Variations in life history of Linyphiid cave spiders. In Proceedings of the 8th International Congress of Speleology, Tampa, FL, USA, 18-24 July 1981; Volume 1, pp. 60-62.

88. Goodnight, C.J.; Goodnight, M.L. Speciation among cave opilionids of the United States. Am. Midl. Nat. 1960, 64, 34-38. [CrossRef]

89. Hedin, M.; Thomas, S.M. Molecular systematics of eastern North American Phalangodidae (Arachnida: Opiliones: Laniatores), demonstrating convergent morphological evolution in caves. Mol. Phylogenet. Evol. 2010, 54, 107-121. [CrossRef]

90. Malcolm, D.R.; Chamberlin, J.C. The pseudoscorpion genus Kleptochthonius Chamberlin (Chelonethida, Chthoniidae). Am. Mus. Nov. 1961, 2063, 1-35.

91. Muchmore, W.B. Redescription of some cavernicolous pseudoscorpions (Arachnida, Chelonethida) in the collection of the Museum of Comparative Zoology. Breviora 1963, 188, 1-16.

92. Muchmore, W.B. The genus Tyrannochthonius in the eastern United States (Pseudoscorpionida: Chthoniidae). Part II. More recently described species. Insecta Mundi 1996, 10, 153-168.

93. Banks, N. Notes on the Pseudoscorpionida. J. N. Y. Entomol. Soc. 1895, 3, 1-13.

94. Vitzthum, H. Die unterirdische Acarofauna. Z. Naturw. 1925, 62, 125-186.

95. Holsinger, J.R. Redescriptions of two poorly known species of cavernicolous rhagidiid mites (Acarina, Trombidiformes) from Virginia and Kentucky. Acarologia 1965, 7, 654-662.

96. Zacharda, M. Soil mites of the family Rhagidiidae (Actinedida: Eupodoidea). Morphology, systematics, ecology. Acta Univ. Carol. Biol. 1980, 1978, 489-785.

97. Cope, E.D. On the Wyandotte Cave and its fauna. Am. Nat. 1872, 6, 406-422. [CrossRef]

98. Loomis, H.F. New cave and epigean millipedes of the United States, with notes on some established species. Bull. Mus. Comp. Zool. 1943, 92, 373-410.

99. Shear, W.A. The milliped family Trichopetalidae, Part 2: The genera Trichopetalum, Zygonopus and Scoterpes (Diplopoda: Chordeumatida, Cleidogonoidea). Zootaxa 2010, 2385, 1-62. [CrossRef]

100. Christiansen, K.A. The genus Arrhopalites (Collembola, Sminthuridae) in the United States and Canada. Int. J. Speleol. 1966, 2, 43-73. [CrossRef]

101. Christiansen, K.; Bellinger, P. Cave Pseudosinella and Oncopodura new to science. J. Cave Karst Stud. 1996, 58, 38-53.

102. Harker, D.F.; Barr, T.C. Western Kentucky coal field: Preliminary investigations of natural features and cultural resources. In Caves and Associated Fauna of the Western Kentucky Coal Field; Technical Report; Kentucky Nature Preserves Commission: Frankfort, KY, USA, 1980; Volume 2.

103. Christiansen, K.A. The genus Pseudosinella (Collembola, Entomobryidae) in caves of the United States. Psyche 1960, 67, 1-25. [CrossRef]

104. Christiansen, K.A. A preliminary survey of the knowledge of North American cave Collembola. Am. Midi. Nat. 1960, 64, 39-44. [CrossRef]

105. Christiansen, K.A. The genus Sinella Brook (Collembola, Entomobryidae) in Nearctic caves. Ann. Entomol. Soc. Am. 1960, 53, 481-491. [CrossRef]

106. Ferguson, L.M. Systematics, Evolution, and Zoogeography of the Cavernicolous Campodeids of the Genus Litocampa (Diplura: Campodeidae) in the United States. Ph.D. Dissertation, Virginia Polytechnic Institute and State University, Blacksburg, VA, USA, 1981.

107. Silvestri, F. Campodeidae (Biospeologica LVI). Arch. Zool. Expo Gen. 1934, 76, 379-383.

108. Silvestri, F. On some Tapygidae in the Museum of Comparative Zoology. Psyche 1947, 51, 209-229. [CrossRef]

109. Conde, B. Campodeides cavernicoles de la region des Appalaches. Notes Biospeol. 1949, 4, 125-139.

110. Ferguson, L.M. Taxonomy, Distribution, and Evolution of Cavernicolous Campodeids in Virginia (Diplura: Campodeidae). Master's Thesis, Virginia Polytechnic Institute and State University, Blacksburg, VA, USA, 1974.

111. Barr, T.C., Jr. The taxonomy, distribution, and affinities of Neaphanops, with notes on associated species of Pseudanophthalmus (Coleoptera, Carabidae). Am. Mus. Nov. 1979, 2682, 1-20.

112. Erichson, W.F. Footnote, p. 384; In Ueber den blinden Fisch der Mammuth-Hohle in Kentucky, mit Bemerkungen uber einige andere in diser Hohle lebenden Thiere; Tellkampf, T. Mullers Arch Anat. Physiol. 1844, 4, 384-394. 
113. Barr, T.C., Jr. Pattern and process in speciation of trechine beetles in eastern North America (Coleoptera: Carabidae: Trechinae). In Taxonomy, Phylogeny, and Biogeography of Beetles and Ants; Ball, G.E., Ed.; Series Entomologia 33; Junk: Dordrecht, The Netherlands, 1985; pp. 350-407.

114. Friedrich, M. Biological clocks and visual systems in cave-adapted animals at the dawn of speleogenomics. Integr. Comp. Biol. 2013, 53, 50-67. [CrossRef]

115. Friedrich, M.; Chen, R.; Daines, B.; Bao, R.; Caravas, J.; Rai, P.K.; Zagmajster, M.; Peck, S.B. Phototransduction and clock gene expression in the troglobiont beetle Ptomaphagus hirtus of Mammoth cave. J. Exp. Biol. 2011, 214, 3532-3541. [CrossRef]

116. Horn, G.H. Catalogue of Coleoptera from south-west Virginia. Trans. Am. Entomol. Soc. 1868, 2, $123-128$.

117. Horn, G.H. Miscellaneous notes and short studies of North American Coleoptera. Trans. Am. Entomol. Soc. 1883, 10, 269-293. [CrossRef]

118. Jeannel, R. Notes sur les Trechini. Bull. Soc. Entomol. Fr. 1920, 1920, 150-155.

119. Jeannel, R. Monographie des Trechinae, 3e livraison. L'Abeille 1928, 35, 1-808.

120. Jeannel, R. Revision des Trechinae de l'Amerique du nord. Arch. Zool. Expo Gen. 1931, 71, 403-499.

121. Jeannel, R. Les coleopteres cavernicoles de la region des Appalaches. III. Etude systematique. Notes Biospeol. 1949, 4, 37-104.

122. Valentine, J.M. New cavernicole Carabidae of the subfamily Trechinae Jeannel. J. Elisha Mitchell Sci. Soc. 1931, 46, 247-258.

123. Valentine, J.M. A classification of the genus Pseudanophthalmus Jeannel (fam. Carabidae) with descriptions of new species and notes on distribution. J. Elisha Mitchell Sci. Soc. 1932, 48, 261-280.

124. Hatch, M.H. Studies on the Leptodiridae (Catopidae) with descriptions of new species. J. N. Y. Entomol. Soc. 1933, 41, 187-239.

125. Park, O. New or little-known species of pselaphid beetles from southeastern United States. J. Tenn. Acad. Sci. 1956, 31, 54-100.

126. Park, O. New or little-known species of pselaphid beetles, chiefly from southeastern United States. J. Tenn. Acad. Sci. 1958, 33, 39-74.

127. Park, O. Cavernicolous pselaphid beetles of the United States. Amer. Midl. Nat. 1960, 64, 66-104. [CrossRef]

128. Barr, T.C., Jr. Non-troglobitic Carabidae (Coleoptera) from caves in the United States. Coleopt. Bull. 1964, 18, 1-4.

129. Barr, T.C., Jr. Cave ecology and the evolution of troglobites. Evol. Biol. 1968, 2, 35-102.

130. Barr, T.C., Jr. Ecology and evolution of cave faunas. In Proceedings of the Third Annual Symposium on the Natural History of the Lower Tennessee and Cumberland River Valleys; Hamilton, S.W., Finley, M.T., Eds.; Center for Field Biology, Austin Peay State University: Clarksville, TN, USA, 1990; pp. 1-19.

131. Barr, T.C., Jr. A Classification and Checklist of the Genus Pseudanophthalmus Jeannel (Coleoptera: Carabidae: Trechinae); Special Publication 11; Virginia Museum of Natural History: Martinsville, VA, USA, 2004; p. 52.

132. Barr, T.C., Jr.; Kuehne, R.A. Ecological studies in the Mammoth Cave System of Kentucky, II: The ecosystem. Ann. Spéléologie 1971, 26, 47-96.

133. Peck, S.B. A systematic revision and evolutionary biology of the Ptomaphagus adelops. Bull. Mus. Comp. Zool. 1973, 145, $29-162$.

134. Peck, S.B. The life cycle of a Kentucky cave beetle, Ptomaphagus hirtus, (Coleoptera; Leiodidae; Catopinae). Int. J. Speleol. 1975, 7, 7-17. [CrossRef]

135. Peck, S.B. Experimental hybridizations between populations of cavernicolous Ptomaphagus beetles (Coleoptera: Leiodidae: Cholevinae). Canad. Entomol. 1983, 115, 445-452. [CrossRef]

136. Peck, S.B. The distribution and evolution of cavernicolous Ptomaphagus beetles in the southeastern United States (Coleoptera; Leiodidae; Cholevinae) with new species and records. Canad. J. Zool. 1984, 62, 730-740. [CrossRef]

137. Peck, S.B. Evolution of adult morphology and life-history characters in cavernicolous Ptomaphagus beetles. Evolution 1986, 40, 1021-1030. [CrossRef]

138. Kane, T.C.; Norton, R.M.; Poulson, T.L. The ecology of a predaceous troglobitic beetle, Neaphaenops tellkampfii (Coleoptera: Carabidae, Trechinae). I. Seasonality of food input and early life history stages. Int. J. Speleol. 1975, 7, 45-54. [CrossRef]

139. Norton, R.M.; Kane, T.C.; Poulson, T.L. The ecology of a predaceous troglobitic beetle, Neaphaenops tellkampfii (Coleoptera: Carabidae, Trechinae). II. Adult seasonality, feeding and recruitment. Int. J. Speleol. 1975, 7, 55-64. [CrossRef]

140. Kane, T.C.; Poulson, T.L. Foraging by cave beetles: Spatial and temporal heterogeneity of prey. Ecology 1976, 57, 793-800. [CrossRef]

141. Laing, C.; Carmody, G.R.; Peck, S.B. Population genetics and evolutionary biology of the cave beetle Ptomaphagus hirtus. Evolution 1976, 30, 484-498. [CrossRef]

142. Giuseffi, S.; Kane, T.C.; Duggleby, W.F. Genetic variability in the Kentucky cave beetle Neaphaenops tellkampfii (Coleoptera: Carabidae). Evolution 1978, 32, 679-681. [CrossRef] [PubMed]

143. Kane, T.C.; Ryan, T. Population ecology of carabid cave beetles. Oecologia 1983, 60, 46-55. [CrossRef] [PubMed]

144. Barr, T.C., Jr.; Holsinger, J.R. Speciation in cave faunas. Ann. Rev. Ecol. Syst. 1985, 16, 313-337. [CrossRef]

145. Kane, T.C.; Brunner, G.D. Geographic variation in the cave beetle, Neaphaenops tellkampfi (Coleoptera: Carabidae). Psyche 1986, 93, 231-251. [CrossRef]

146. Helf, K.L. Foraging Ecology of the Cave Cricket Hadenoecus subterraneus: Effects of Climate, Ontogeny, and Predation. Ph.D. Dissertation, University of Illinois at Chicago, Chicago, IL, USA, 2003.

147. Leray, V.L.; Caravas, J.; Friedrich, M.; Zigler, K.S. Mitochondrial sequence data indicate "Vicariance by Erosion" as a mechanism of species diversification in North American Ptomaphagus (Coleoptera, Leiodidae, Cholevinae) cave beetles. Subterr. Biol. 2019, 29, 35-57. [CrossRef] 
148. Marshall, S.A.; Peck, S.B. Distribution of cave-dwelling Sphaeroceridae (Diptera) of eastern North America. Proc. Entomol. Soc. Ontario 1984, 115, 37-41.

149. De Beachamp, P. Turbellaries triclades (Biospeologica LVI). Arch. Zool. Expo Gen. 1931, 71, 317-331.

150. Hyman, L.H. Studies on the morphology, taxonomy, and distribution of North American triclad Turbellaria. VIII. Some cave planarians of the United States. Trans. Am. Micr. Soc. 1937, 56, 457-477. [CrossRef]

151. Carpenter, J.H. Systematics and Ecology of Cave Planarians of the United States. Ph.D. Thesis, University of Kentucky, Lexington, KY, USA, 1970.

152. Carpenter, J.H. Observations on the biology of cave planarians of the United States. Int. J. Speleol. 1982, 12, 9-26. [CrossRef]

153. Kenk, R. Freshwater triclads (Turbellaria) of North America, IX. The genus Sphalloplana. Smithson. Contrib. Zool. 1977, $246,1-38$. [CrossRef]

154. Pearson, W.D.; Boston, C.H. Distribution and Status of the Northern Cavefish; Amblyopsis Spelaea, Final Report; Nongame and Endangered Wildlife Program, Indiana Department of Natural Resources: Indianapolis, IN, USA, 1995.

155. Hershler, R.; Hubricht, L. Notes on Antroselates Hubricht, 1963 and Antrobia Hubricht, 1971 (Gastropoda: Hydrobiidae). Proc. Biol. Soc. Wash. 1988, 101, 730-740.

156. Niemiller, M.L.; Poulson, T.L. Subterranean fishes of North America: Amblyopsidae. In The Biology of Subterranean Fishes; Trajano, E., Bichuette, M.E., Kappor, B.G., Eds.; Science Publishers: Enfield, NH, USA, 2010; pp. 169-280.

157. Kofoid, C.A. The plankton of Echo River, Mammoth Cave. Trans. Am. Micr. Soc. 1899, 21, 113-126. [CrossRef]

158. Chappuis, P.A. Crustaces copepodes (Biospeologica LVI). Arch. Zool. Expo Gen. 1931, 71, 345-360.

159. Whitman, R.L. Meiofaunal Sampling at Mammoth Cave National Park. Draft Report; National Park Service, Indiana Dunes National Lakeshore: Chesterton, IN, USA, 1989.

160. Lewis, J.J. Conservation Assessment for Northern Cavefish Copepod (Cauloxenus stygius). Report; USDA Forest Service: Eastern Region, Ghana, 2002.

161. Klie, W. Crustaces ostracodes (Biospeologica LVI). Arch. Zool. Expo Gen. 1931, 71, 333-344.

162. Hart, C.W., Jr.; Hobbs, H.H., Jr. Eight new troglobitic ostracods of the genus Entocythere (Crustacea, Ostracoda) from the eastern United States. Proc. Acad. Nat. Sci. USA 1961, 113, 173-185.

163. Hart, C.W., Jr.; Hart, D.G. Four new entocytherid ostracods from Kentucky, with notes on the troglobitic Sagittocythere barri. Nolulae Nat. 1966, 388, 1-10.

164. Hart, D.G.; Hart, C.W., Jr. The ostracod family Entocytheridae. Acad. Nat. Sci. Phila. Monogr. 1974, 18, 1-239.

165. Garman, H. The origin of the cave fauna of Kentucky, with a description of a new blind beetle. Science 1892, $20,240-241$. [CrossRef] [PubMed]

166. Hay, W.P. Observations on the crustacean fauna of the region about Mammoth Cave, Kentucky. Proc. U.S. Nat. Mus. 1902, 25, 223-236. [CrossRef]

167. Giovanolli, L. Invertebrate life of Mammoth and other neighboring caves. Pp. 600-623 In: V. Bailey. Cave Life of Kentucky. Am. Midl. Nat. 1933, 14, 385-635.

168. Chappuis, P.A. Biospeologica 71: Campagne speologique de C. Bolivar et R. Jeannel dans PAmerique du Nord (1928), 13, Asellides. Arch. Zool. Expo Gen. 1950, 87, 177-182.

169. Lewis, J.J.; Bowman, T.E. The subterranean asellids (Caecidotea) of Illinois (Crustacea: Isopoda: Asellidae). Smithson. Contrib. Zool. 1981, 335, 1-66. [CrossRef]

170. Helf, K.L.; Moore, W.; Wells, B. Monitoring Cave Aquatic Biota at Selected Parks in the Cumberland Piedmont Network: Protocol Narrative-Version 1.0. Natural Resource Report NPS/CUPN/NRR—2018/1705; National Park Service: Fort Collins, CO, USA, 2018.

171. Zhang, J.; Holsinger, J.R. Systematics of the freshwater amphipod genus Crangonyx (Crangonyctidae) in North America. Va. Mus. Nat. Hist. Memoir. 2003, 6, 1-274.

172. Holsinger, J.R. Freshwater Amphipod Crustaceans (Gammaridae) of North America, Biota of Freshwater Ecosystems, Identification Manual No. 5; U.S. Environmental Protection Agency: Washington, DC, USA, 1972.

173. Zhang, J. Systematics of the Freshwater Amphipod Genus Crangonyx (Crangonyctidae) in North America. Ph.D. Dissertation, Old Dominion University, Norfolk, VA, USA, 1997.

174. United States Fish \& Wildlife Service. Kentucky Cave Shrimp (Palaemonias ganteri), 5-Year Review: Summary and Evaluation; Southeast Region, Kentucky Ecological Services Field Office: Frankfort, KY, USA, 2016.

175. Fage, L. Crustaces amphipodes et decapodes. In: Biospeologica, LVI: Campagne speologique de C. Bolivar et R. Jeannel dans l'Amerique du Nord (1928). Arch. Zool. Exp. Gen. 1931, 71, 361-374.

176. Hobbs, H.H., Jr.; Hobbs, H.H., III; Daniel, M.A. A review of the troglobitic decapod crustaceans of the Americas. Smithson. Contrib. Zool. 1977, 244, 1-83. [CrossRef]

177. Holsinger, J.R.; Leitheuser, A.T. Ecological Analysis of the Kentucky Cave Shrimp, Palaemonias ganteri Hay, Mammoth Cave National Park (Phase I), Final Report; Old Dominion Research University Foundation: Norfolk, VA, USA, 1982.

178. Holsinger, J.R.; Leitheuser, A.T. Ecological Analysis of the Kentucky Cave Shrimp, Palaemonias ganteri Hay, Mammoth Cave National Park (Phase II), Final Report; Old Dominion Research University Foundation: Norfolk, VA, USA, 1982.

179. Holsinger, J.R.; Leitheuser, A.T. Ecological analysis of the Kentucky Cave Shrimp, Palaemonias ganteri Hay, Mammoth Cave National Park (Phase III), Final Report; Old Dominion Research University Foundation: Norfolk, VA, USA, 1983. 
180. Lisowski, E.A. The endangered Kentucky blind cave shrimp. In Proceedings of the National Cave Management Symposium, Carlsbad, New Mexico and Mammoth Cave National Park, Kentucky; Wilson, R.C., Lewis, J.J., Eds.; Pygmy Dwarf Press: Oregon City, OR, USA, 1982; pp. 138-142.

181. Lisowski, E.A. Distribution, habitat, and behavior of the Kentucky cave shrimp Palaemonias ganteri Hay. J. Crustacean Biol. 1983, 3 , 88-92. [CrossRef]

182. Lisowski, E.A.; Poulson, T.L. Impacts of Lock and Dam Six on base level ecosystems in Mammoth Cave. In Cave Research Foundation 1979 Annual Report; The Cave Research Foundation: Cave, KY, USA, 1981; pp. 48-54.

183. Leitheuser, A.T.; Holsinger, J.R. Ecological Analysis of the Kentucky Cave Shrimp, Palaemonias ganteri Hay, Mammoth Cave National Park (Phase IV), Final Report; Old Dominion University Research Foundation: Norfolk, VA, USA, 1983.

184. Leitheuser, A.T.; Holsinger, J.R.; Olson, R.; Pace, N.R.; Whitman, R.L.; White, T. Ecological Analysis of the Kentucky Cave Shrimp, Palaemonias ganteri Hay, at Mammoth Cave National Park (Phase V), Final Report; Old Dominion University Research Foundation: Norfolk, VA, USA, 1985.

185. Leitheuser, A.T.; Whitman, R.L.; Gochee, A.V.; Holsinger, J.R. Ecological Analysis of the Kentucky Cave Shrimp, Palaemonias ganteri Hay, at Mammoth Cave National Park (Phase VI), Final Report; Old Dominion University Research Foundation: Norfolk, VA, USA, 1986.

186. United States Fish \& Wildlife Service. Kentucky Cave Shrimp Recovery Plan; United States Fish \& Wildlife Service: Atlanta, GA, USA, 1988.

187. Pearson, W.D.; Jones, T.G. A Final Report Based on a Faunal Inventory of Subterranean Streams and Development of a Cave Aquatic Biological Monitoring Program Using a Modified Index of Biotic Integrity, Final Report; National Park Service, Mammoth Cave National Park: Brownsville, KY, USA, 1998.

188. Cooper, J.E.; Cooper, M.R. Observations on the biology of the endangered stygobiotic shrimp Palaemonias alabamae, with notes on P. ganteri (Decapoda: Atyidae). Subterr. Biol. 2011, 8, 9-20. [CrossRef]

189. Stump, A.J. The Use of Environmental DNA for the Detection of Palaemonias ganteri (Hay, 1901), a Federally Endangered Species. Master's Thesis, Eastern Kentucky University, Richmond, KY, USA, 2019.

190. Hagen, H.H. Monograph of the North American Astacidae. Illus. Cat. Mus. Com. Zool. 1870, 3, 1-109.

191. Hagen, H.H. The blind crayfish. Am. Nat. 1872, 6, 494.

192. Garman, H. A little-known cave crayfish. Trans. Ky. Acad. Sci. 1924, 1, 87-94.

193. Park, O.; Roberts, T.W.; Harris, S.J. Preliminary analysis of activity of the cave crayfish, Cambarus pellucidus. Am. Nat. 1941, 75, 154-171. [CrossRef]

194. Rhoades, R. The crayfishes of Kentucky, with notes on variation, distribution and descriptions of new species and subspecies. Am. Midl. Nat. 1944, 31, 111-149. [CrossRef]

195. Hobbs, H.H., Jr.; Barr, T.C., Jr. Origins and affinities of the troglobitic crayfishes of North America (Decapoda: Astacidae), I: Genus Cambarus. Am. Midl. Nat. 1960, 64, 12-33. [CrossRef]

196. Hobbs, H.H., Jr.; Barr, T.C., Jr. Origins and affinities of the troglobitic crayfishes of North America (Decapoda: Astacidae), II: Genus Orconectes. Smithson. Contrib. Zool. 1972, 105, 1-84. [CrossRef]

197. Brown, F.A. Diurnal rhythm in cave crayfish. Nature 1961, 191, 929-930. [CrossRef]

198. Wolfe, D.A.; Cornwell, D.G. Carotenoids of cavernicolous crayfish. Science 1964, 144, 1467-1469. [CrossRef]

199. Compson, Z.G. An Isotopic Examination of Cave, Spring and Epigean Trophic Structures in Mammoth Cave National Park. Master's Thesis, Western Kentucky University, Bowling Green, KY, USA, 2004.

200. Taylor, C.A.; Schuster, G.A. The Crayfishes of Kentucky; Illinois Natural History: Champaign, IL, USA, 2004.

201. Proudlove, G.S. Subterranean Fishes of the World; International Society for Subterranean Biology: Moulis, France, 2006.

202. Davidson, R. An Excursion to the Mammoth Cave and the Barrens of Kentucky, with Some Notices of the Early Settlement of the State; A.T. Skillman and Son, Lexington; Thomas Cowperthwait and Co.: Philadelphia, PA, USA, 1840.

203. Thompson, W. Notice of the blindfish, crayfish, and insects from Mammoth Cave, Kentucky. Ann. Mag. Nat. Hist. 1844, 13, 3.

204. Girard, C.F. Ichthyological notices. Proc. Acad. Nat. Sci. USA 1860, 1859, 56-68.

205. Woods, L.P.; Inger, R.F. The cave, spring, and swamp fishes of the family Amblyopsidae of central and eastern United States. Am. Midl. Nat. 1957, 58, 232-256. [CrossRef]

206. Poulson, T.L. Cave Adaptation in Amblyopsid Fishes. Ph.D. Dissertation, Department of Zoology, University of Michigan," Ann Arbor, MI, USA, 1961.

207. Poulson, T.L. Cave adaptation in amblyopsid fishes. Am. Midl. Nat. 1963, 70, 257-290. [CrossRef]

208. Poulson, T.L. Cave Research Foundation Annual Report; Aquatic Cave Communities: Washington, DC, USA, 1968; pp. 16-18.

209. Barr, T.C., Jr.; Kuehne, R.A. The cavefish, Amblyopsis spelaea, in northern Kentucky. Copeia 1962, 1962, 662. [CrossRef]

210. Rosen, D.E. Comments on the relationships of the North American cave fishes of the family Amblyopsidae. Am. Mus. Nov. 1962, 2109, 1-35.

211. Poulson, T.L.; White, W.B. The cave environment. Science 1969, 165, 971-981. [CrossRef] [PubMed]

212. Clay, W.M. The Fishes of Kentucky; Kentucky Department of Fish and Wildlife Resources: Frankfurt, KY, USA, 1975.

213. Swofford, D.L.; Branson, B.A.; Sievert, G. Genetic differentiation of cavefish populations (Amblyopsidae). Isozyme Bull. 1980, 13, 109-110.

214. Swofford, D.L. Genetic Variability, Population Differentiation, and Biochemical Relationships in the Family Amblyopsidae. Master's Thesis, Eastern Kentucky University, Richmond, KY, USA, 1982. 
215. Burr, B.M.; Warren, M.L., Jr. A Distributional Atlas of Kentucky Fishes, Vol. 4; Kentucky State Nature Preserves Commission Scientific and Technical Series: Frankfort, KY, USA, 1986.

216. Lewis, J.J. Conservation Assessment for Southern Cavefish (Typhlichthys subterraneus) Report; USDA Forest Service: Eastern Region, Ghana, 2002.

217. Keith, J.H. Distribution of Northern cavefish, Amblyopsis spelaea DeKay, in Indiana and Kentucky and recommendations for its protection. Nat. Areas J. 1988, 8, 69-79.

218. Branson, B.A. The Mammoth Cave blindfish. Trop. Fish Hobbyist 1991, 40, 39-40.

219. Romero, A. Threatened fishes of the world: Typhlichthys subterraneus Girard, 1860 (Amblyopsidae). Environ. Biol. Fishes 1998, 53, 74. [CrossRef]

220. Romero, A.; Bennis, L. Threatened fishes of the world: Amblyopsis spelaea DeKay, 1842 (Amblyopsidae). Environ. Biol. Fishes 1998, 51, 421-428. [CrossRef]

221. Niemiller, M.L. Evolution, Speciation, and Conservation of Amblyopsid Cavefishes. Ph.D. Dissertation, University of Tennessee, Knoxville, TN, USA, 2011.

222. Niemiller, M.L.; Fitzpatrick, B.M. Status and life history of the amblyopsid cavefishes in Kentucky. Ky. Dept. Fish Wildl. Resour. 2012, 5, 9-15.

223. Niemiller, M.L.; Near, T.J.; Fitzpatrick, B.M. Delimiting species using multilocus data: Diagnosing cryptic diversity in the southern cavefish, Typhlichthys subterraneus (Teleostei: Amblyopsidae). Evolution 2012, 66, 846-866. [CrossRef]

224. Hart, P.B.; Niemiller, M.L.; Burress, E.D.; Armbruster, J.W.; Ludt, W.B.; Chakrabarty, P. Cave-adapted evolution in the North American amblyopsid fishes inferred using phylogenomics and geometric morphometrics. Evolution 2020, 74, 936-949. [CrossRef]

225. Culver, D.C.; Sket, B. Hotspots of subterranean biodiversity in caves and wells. J. Cave Karst Stu. 2000, 62, 11-17.

226. Culver, D.C.; Pipan, T. Subterranean ecosystems. In Encyclopedia of Biodiversity, 2nd ed.; Levin, S.A., Ed.; Elsevier: Amsterdam, The Netherlands, 2013.

227. Hutchins, B.T.; Gibson, J.R.; Diaz, P.H.; Schwartz, B.F. Stygobiont diversity in the San Marcos Artesian Well and Edwards Aquifer groundwater ecosystem, Texas, USA. Diversity 2021, 13, 234. [CrossRef]

228. Culver, D.C.; Deharveng, L.; Bedos, A.; Lewis, J.J.; Madden, M.; Reddell, J.R.; Sket, B.; Trontelj, P.; White, D. The mid-latitude biodiversity ridge in terrestrial cave fauna. Ecography 2006, 29, 120-128. [CrossRef]

229. Olson, R. Potential effects of hydrogen sulfide and hydrocarbon seeps on Mammoth Cave ecosystems. In Mammoth Cave National Park's 10th Research Symposium; Mammoth Cave National Park: Brownsville, KY, USA, 2013; pp. 25-30.

230. Niemiller, M.L.; Bichuette, E.; Taylor, S.J. Conservation of cave fauna in Europe and the Americas. In Ecological Studies: Cave Ecology; Moldovan, O.T., Kovac, L., Halse, S., Eds.; Springer: Dordrecht, The Netherlands, 2018; pp. 451-478.

231. Mammola, S.; Cardoso, P.; Culver, D.C.; Deharveng, L.; Ferreira, R.L.; Fiŝer, C.; Galassi, D.M.P.; Griebler, C.; Halse, S.; Humphreys, W.F.; et al. Scientists' warning on the conservation of subterranean ecosystems. BioScience 2019, 69, 641-650. [CrossRef]

232. Brucker, R. Conservation at Mammoth Cave. In Cave Research Foundation 1979 Annual Report; Mammoth Cave National Park: Brownsville, KY, USA, 1979; pp. 40-41.

233. Pfaff, R.M.; Glennon, J.A.; Groves, C.G.; Anderson, M.; Fry, J.; Meiman, J. Landuse and water quality threats to the Mammoth Cave karst aquifer, Kentucky. In Proceedings of the 12th National Cave and Karst Management Symposium, Chattanooga, TN, USA, 19-22 October 1999.

234. Meiman, J.; Hopper, H.L.; Brucker, R.W. Management issues and threats to the longest cave. In Proceedings of the 15th National Cave and Karst Management Symposium, Tucson, AZ, USA, 16-19 October 2001.

235. Toomey, R.; Thomas, S.; Gillespie, J.; Carson, V.; Trimboli, S.R. White-nose Syndrome at Mammoth Cave National Park: Actions before and after its detection. In Proceedings of the 10th Mammoth Cave Research Symposia, Mammoth Cave, KY, USA, 14-15 February 2013; p. 13.

236. Olson, R.A. Environmental issues relevant to the Mammoth Cave area. In Mammoth Cave: A Human and Natural History, Cave and Karst Systems of the World; Hobbs, H.H., III, Olson, R.A., Winkler, E.G., Culver, D.C., Eds.; Springer: Berlin/Heidelberg, Germany, 2017; pp. 265-275.

237. Ruhl, M. Flow Reversal Events Increase the Abundance of Nontroglobitic Fish in the Subterranean Rivers of Mammoth Cave National Park. Master's Thesis, Western Kentucky University, Bowling Green, KY, USA, 2005.

238. Trimboli, S.R.; Weber, K.; Ryan, S.; Toomey, R.S. An overview of the reverse flow patterns of River Styx in Mammoth Cave, Kentucky: 2009-2012. In Proceedings of the 11th Mammoth Cave Research Symposia, Mammoth Cave, KY, USA, $18-20$ April 2016.

239. Trimboli, S.R.; Toomey, R.S. Temperature and reverse-flow patterns of the River Styx, Mammoth Cave, Kentucky. J. Cave Karst Stud. 2019, 81, 174-187. Available online: https://digitalcommons.wku.edu/mc_reserch_symp/11th_Research_Symposium_20 16/Day_three/3 (accessed on 28 June 2021). [CrossRef]

240. Niemiller, M.L.; Taylor, S.J.; Slay, M.E.; Hobbs, H.H., III. Biodiversity in the United States and Canada. In Encyclopedia of Caves, 3rd ed.; Culver, D.C., White, W.B., Pipan, T., Eds.; Academic Press: Cambridge, MA, USA, 2019; pp. $163-177$.

241. Lewis, J.J.; Lewis, S.L. Cave fauna study for the Interstate 66 EIS (Somerset to London, Kentucky). In Proceedings of the 2005 National Cave and Karst Management Symposium, Albany, NY, USA, 31 October-4 November 2005; pp. 15-20.

242. Muchmore, W. New terrestrial isopods of the genus Miktoniscus from eastern United States (Crustacea: Isopoda: Oniscoidea). Ohio J. Sci. 1964, 64, 51-57. 
243. Zakšek, V.; Sket, B.; Gottstein, S.; Franjević, D.; Trontelj, P. The limits of cryptic diversity in groundwater: Phylogeography of the cave shrimp Troglocaris anophthalmus (Crustacea: Decapoda: Atyidae). Mol. Ecol. 2009, 18, 931-946. [CrossRef] [PubMed]

244. Ethridge, J.Z.; Gibson, J.R.; Nice, C.C. Cryptic diversity within and amongst spring-associated Stygobromus amphipods (Amphipoda: Crangonyctidae). Zool. J. Linn. Soc. 2013, 167, 227-242. [CrossRef]

245. Devitt, T.J.; Wright, A.M.; Cannatella, D.C.; Hillis, D.M. Species delimitation in endangered groundwater salamanders: Implications for aquifer management and biodiversity conservation. Proc. Natl. Acad. Sci. USA 2019, 116, 2624-2633. [CrossRef] [PubMed] 